\title{
Local Beta: Has Local Real Estate Market Risk Been Priced in REIT Returns?
}

\author{
Bing Zhu ${ }^{1} \cdot$ Colin Lizieri $^{2}$ i
}

Accepted: 28 January 2022

(c) The Author(s) 2022, corrected publication 2022

\begin{abstract}
This paper studies the pricing of the risk associated with the location of the assets. The local real estate market risk is measured by 'local beta', which combines the systematic risk of local property markets and the property allocation strategy of real estate firms. The empirical results confirm a higher equity return for a firm with higher exposure to the most volatile property markets, particularly for REITs which are more geographically concentrated. For REITs with highly diversified assets, local real estate risks are not reflected in REIT returns. For those REITs with most concentrated assets, a one standard deviation increase in the local beta will lead to a $4.7 \%$ increase in the annual return. Investors can use REITs' local real estate risk as an information tool to construct a long-short investment portfolio of real estate firms and can achieve a significant non-market performance of $4.9 \%$ per annum.
\end{abstract}

Keywords Geographic asset location · Real estate returns · Local real estate risk · Diversification

\section{JEL Classification $\mathrm{G} 12 \cdot \mathrm{R} 3$}

\section{Introduction}

The importance of location on property investment has been highlighted in the literature. Recently, there is an emerging literature on identifying locational factors for listed real estate firms. Most REITs have a diversified property portfolio.

Colin Lizieri

cm149@cam.ac.uk

Bing Zhu

b.zhu@tum.de

1 School of Engineering and Design, Technical University of Munich, Arcisstraße 21, 80333 Munich, Germany

2 Department of Land Economy, University of Cambridge, 19 Silver Street, Cambridge CB3 9EP, UK 
Therefore, the question arises as to whether the location of the underlying properties still matters for REIT performance. Various measures have been employed. Some literature focuses on the 'quality' of the location, including exposure to the so-called 'Gateway' markets (Ling et al., 2018a), the risk-adjusted property market portfolio returns (Ling et al., 2020a), and locational characteristics such as density and locational economic risks (Fisher et al., 2020). Other literature investigates the distance of properties from firm headquarters (Ling et al., 2018b; Milcheva et al., 2021). Spatial econometric modelling has also been used to quantify the impact of the locational factors (Zhu \& Milcheva, 2020). If the location of assets affects REIT performance, REITs with more geographically-overlapping assets should exhibit stronger co-movements in their equity returns. Moreover, the risks associated with geographically-determined natural disasters or pandemics have also been used as a measurement of location quality (Ling et al., 2020b; Rehse et al., 2019; Xie \& Milcheva, 2020).

This paper proposes a new location risk factor - the "beta risk" of the local property markets where REITs allocate their assets. It captures the sensitivity of the underlying property markets to any aggregate shocks. It reflects the systematic risk and cyclicality of the local real estate markets. The impact of location risk on a firm's performance has been studied in the general finance literature. For instance, focusing on local economic cyclicality and industry bases, Tuzel and Zhang (2017) propose two channels - wages and rental rates - because both labour and property markets are segmented. While procyclical wages provide a natural hedge against aggregate shocks and reduce firm risk, procyclical prices of real estate, which are part of firm assets, increase firm risk. Our local beta drew from Tuzel and Zhang (2017), which emphasizes the segmentation of real estate markets. As a result, a nationwide real estate market factor will be insufficient as as a measure of real estate market risk. However, unlike Tuzel and Zhang (2017), which focuses on local industrial composition and business conditions, our local beta is more specific to the local property market conditions, such as supply elasticity and liquidity. ${ }^{1}$ For a firm with high exposure to risky real estate markets, the value of its underlying assets should respond more strongly to the aggregate shock than a firm with low exposure to risky markets. When the assets' quality is not easily observable, investors may depend on conditions in the overall real estate market (Liu et al., 2019). As a result, REIT investors may perceive a higher risk in this REIT's equity and, therefore, demand higher returns in compensation. Additionally, even though the REIT structure typically provides investors with access to skilled property managers with diversified property holdings, the beta risks of local real estate markets reflect a non-diversifiable component of spatial risks, and therefore, may be priced into the REIT equity returns.

\footnotetext{
1 Indeed, Fisher et al. (2020) do not find significant impact of the local real estate market risk measured by the local economic conditions on the REIT returns. Instead, zip-code level employment density influences REIT performance. Ling et al. (2020a) show that the private information of the local property market, which is measured by the risk-adjusted property portfolio returns, can predict the cross-sectional return of REITs, indicating the diffusion of asset information to the stock price.
} 
Using REIT data from 1998 to 2015, this paper confirms a significant premium for the beta risks of underlying property markets for REITs. For robustness, issues regarding self-selection, valuation smoothing, and leverage are addressed: this conclusion remains supported. Thus far, in much if the REIT asset pricing literature, REITs are studied as common stocks, and beta strategies are largely at the firm level based on financial characteristics or exposure to stock market risks. ${ }^{2}$ REITs' dual nature - their close link to the real estate markets - has not been well incorporated. Our findings fill this literature gap by showing that investors can optimise their mix of REITs according to their exposure to risky real estate markets using a "smart local beta" strategy. An investment strategy that sells REITs with high exposure to high beta areas and buys high exposure to low beta areas could have earned a nonmarket return of nearly $5 \%$ per year.

Although the systematic risk of local real estate markets is priced in REIT equity returns, geographic diversification allows REITs to limit their exposure to the high beta markets. As a result, investors perceive REITs with geographically diversified portfolios to be less prone to those local market shocks and so do not demand a return premium. Prior literature on diversification has tried to understand the benefits/costs of diversification from management costs (Capozza \& Seguin, 1998; Capozza \& Seguin, 1999; Hartzell et al., 2014), information asymmetry (Ling et al., 2018b), investor recognition (Garcia \& Norli, 2012) and management alignment (Wang et al., 2017). We add to this literature in showing that diversification affects firms' returns by reducing the perceived risks of equity holdings. When REITs invest over 12 or more metropolitan statistical areas (MSAs), REIT equity returns should not be significantly affected by the local real estate risk. ${ }^{3}$

Last but not least, this project also provides new evidence on the question: do listed real estate firms behave more like direct real estate or general stocks? Although this topic has been intensively studied, nearly all prior literature has focused on time variation in the aggregated risk and return of the real estate, stock, and REIT investments. For instance, many studies compare the long-term and/or short term co-movement between real estate, stock and REIT returns (see, e.g. (Glascock et al., 2000, Morawski et al., 2008, Oikarinen et al., 2011, Pagliari et al., 2005, Schätz \& Sebastian, 2011, Serrano \& Hoesli, 2010, Simon \& Ng, 2009, Sing et al., 2006, Westerheide, 2006). Others have investigated the pricing of real estate and stock

\footnotetext{
${ }^{2}$ For instance, Peterson and Hsieh (1997) investigate stock, bond and real estate market factors, and show that variations in REIT returns are fully explained by the three Fama-French risk factors. The real estate risk factor story is rejected. Chatrath et al. (2000) and Chiang et al. (2004) show that equity REIT betas are higher in declining markets than in advancing markets. Based on a dual-beta asset pricing model, Conover et al. (2000) find a positive relationship between cross-sectional REIT return and betas only in both January and non-January months. During bear market months, no significant relationship is found. Shen et al. (2020) find that high-beta REITs earn significantly lower risk-adjusted returns than low-beta REITs, indicating beta anomaly for REITs.

${ }^{3}$ We note that investors can, of course, diversify their equity holdings by building diversified portfolios of REITs, assuming they can identify the spatial risks they face. This will diversify idiosyncratic spatial risks, but not those that relate to systematic spatial factors that might not otherwise be captured in factor models. Further, passive investment strategies, such as an index tracking approach, could result in concentration of spatial risk.
} 
risks (Anderson et al., 2005; Kroencke et al., 2018). However, nearly all studies used aggregated index returns. Due to the fact that property markets are segmented, with different cyclical patterns, it may not be enough to use nationwide real estate indices to proxy the performance of heterogeneous direct real estate markets. For instance, Gyourko and Nelling (1996) show that the systematic risk of equity REITs varies by the type of property and the economic regions in which the property locates.

Our empirical results show that REIT equity returns are generally more sensitive to stock market risk, consistent with the previous literature. A one standard deviation increase in the local beta will result in a $1.6 \%$ increase in REIT equity returns, while a one standard deviation increase in stock beta is associated with a $2.5 \%$ increase in REIT equity returns. However, extending prior work, this study finds that the sensitivity to local real estate market risk varies across REITs according to their spatial diversification strategy. For REITs with the most concentrated assets, a one standard deviation increase in the local beta will result in an up to $4.7 \%$ increase in REIT equity returns, which is higher than the impact of stock market risk.

We proceed as follows: Section 2 summarizes the literature review. Section 3 describes our data and discussed the methodology used, Section 4 describes the findings and Section 5 concludes.

\section{Literature Review}

This paper is closely related to a large and rapidly growing literature on how economic decision making is influenced by firms' geographic location. In the finance literature, work in this vein mostly concentrates on the location of the firm's headquarters (Becker et al., 2011; Bernile et al., 2015; Hong et al., 2008; Pirinsky \& Wang, 2006; Tuzel \& Zhang, 2017); some studies focus on the location of assets related to the firm (Garcia \& Norli, 2012). For example, using U.S. company data from 1993 to 2002, Pirinsky and Wang (2006) document strong co-movement in the stock returns of firms headquartered in the same geographic area. The local co-movement of stock returns is not explained by economic fundamentals and is stronger for smaller firms with more individual investors. Price formation in equity markets has a significant geographic component linked to the trading patterns of local residents. Coval and Moskowitz (2001) argue that geographic proximity matters, as local fund managers can access local information more easily and monitor the operations of local companies. Hong et al. (2008) identify a word-ofmouth channel, which means that fund managers in the same location can have correlated strategies. The limitation of using headquarters location as a proxy for the geographical distribution of the firm's operating activities has been recognised in recent papers. Fu and Gupta-Mukherjee (2014) argue that in financial markets which are characterised by large frictions in the dissemination of information, market participants can acquire information through informal channels such as the links between funds and the links between funds and companies. Garcia and Norli (2012) study the geographic dispersion of the firm's operations by counting the number of state names from annual reports filed with the SEC on Form 10-K. They find that the stock returns of truly local firms far exceed the stock returns of 
geographically-dispersed firms, and the premium for being local is due to the lower investor recognition for local firms, resulting in higher stock returns to compensate investors for insufficient diversification.

The impact of location of underlying assets has been more widely studied in the real estate literature. ${ }^{4}$ The trade-off between the benefits and costs of being local has been extensively discussed. There was an early focus on management costs. For instance, (Capozza \& Seguin, 1998; Capozza \& Seguin, 1999), show that allocating properties in different regions may result in higher administrative costs and a higher liquidity premium that offset the benefits of diversification. More recent literature shows that there is an information advantage to being local. Ling et al. (2018b) document that managers tend to overweight asset allocations to their local market to exploit their perceived information advantage. There is a significant positive relation between home market concentration and firm returns. Wang et al. (2017) find a consistently negative relationship between the distance from headquarters and cumulative abnormal returns (CARs), confirming management alignment theory: proximity between the headquarter and underlying properties is associated with poor shareholder protection due to better employee protection. In particular, for headquarters in less-populated MSAs, the managerial alignment effect dominates the information asymmetry effect. However, Feng et al. (2019) find that operating efficiency and improved transparency can offset the diversification discount. Milcheva et al. (2020) find a higher non-market return for REITs with more diversified assets after the global financial crisis.

Only a few studies focus on the riskiness of local markets and their impact on stock returns. Using headquarters as a proxy for location, Tuzel and Zhang (2017) show that the headquarter location affects firm risk through local factor prices via pro-cyclical wages, which provide a natural hedge against aggregate shocks and reduce firm risk. So firms located in higher local beta areas have lower industryadjusted returns and conditional betas, with the effect stronger among firms with low real estate holdings. Tuzel and Zhang (2017) also addressed the limitation of using headquarters as the proxy for a firm's business locations. REITs constitute an ideal samplefor investigating the impact of location of underlying assets on firm performance. Gyourko and Nelling (1996) show that the systematic risk of equity REITs varies by the type of property and the economic regions in which the property locates. However, they did not identify the channel of the difference. More recently, Fisher et al. (2020) study the locational characteristics, particularly the density, and show that REITs with property holdings in high-density locations experience higher NOI growth, earn higher risk-adjusted returns, and carry higher systematic risk than their otherwise comparable peers in low-density locations. Ling et al. (2020a) propose a novel measurement to calculate a "property portfolio return" for individual REITs based on the geographic distribution of properties and private real estate returns (using MSA level NCREIF data). They then adjust these returns for REIT systematic risk factors (national sensitivity to real estate and financial

\footnotetext{
4 See, e.g., Gyourko and Nelling (1996), Capozza and Seguin (1998), Ambrose et al. (2000), Hartzell et al. (2014), Ling et al. (2018a) and many others.
} 
market variables) and find that the risk-adjusted property portfolio returns (characterised as alpha) have predictive power in explaining future REIT returns. They argue this shows a slow information diffusion process from private to public markets (in contrast to previous research that finds price discovery effects from public to private markets). Unlike Ling et al. (2020a), our study focuses on the beta risk of the local real estate markets. Our work has a stronger focus on risk and, specifically, the impact of local real estate market volatility on the required returns of REIT investors. The proposed real estate beta risk extends REITs' risk factor from the capital market risk at the firm level to the property markets at the asset level.

\section{Data}

\section{Local beta}

Local beta is the key explanatory variable in this paper. Based on the property portfolio of each firm, we calculate the average systematic risk of all local markets where the firms' properties are located:

$$
\beta_{i, t}^{\mathrm{LREM}}=\sum_{m=1}^{M} w_{m . i, t} \beta_{m}
$$

where $\beta_{m}$ is the MSA beta, and $w_{m . i, t}$ represents the share of properties of firm $i$ in each market at period $t . w_{m_{i} i, t}$ is calculated as the number of properties located in MSA $m$ to total properties ${ }^{5}$ and the local data of REIT property portfolio are extracted from the SNL database. For instance, if REIT A has $80 \%$ of properties located in the New York MSA and $20 \%$ of properties located in Miami, $\beta_{i, t}^{\text {LREM }}$ for REIT A will be calculated as $\beta_{i, t}^{\mathrm{LREM}}=\sum_{m=1}^{2} w_{m . i, t} \beta_{m}=80 \% * \beta_{N Y}+20 \% * \beta_{M I A M I}$. It should be noted that although $\beta_{m}$ is constant over time, $\beta_{i, t}^{\mathrm{LREM}}$ may change given the change in the REIT's property portfolio constitutents.

$\beta_{m}$ reflects the sensitivity of local commercial real estate prices in each MSA to any systematic real estate shocks, and it is calculated as ${ }^{6}$ :

$$
r_{m, q}^{N P I}-r_{f, q}=\alpha_{m}+\beta_{m}\left(M K T_{q}^{N P I}-r_{f, q}\right)+\varepsilon_{m, q}
$$

where $r_{m, q}^{N P I}$ is the direct real estate returns in market $m$ in quarter $q$. We collect National Council of Real Estate Investment Fiduciaries' (NCREIF) non-profit institution (NPI) total returns for commercial real estate in 144 Core based statistical

\footnotetext{
5 Alternatively, the share can also be calculated using property size or adjusted cost. Adjusted cost is as the maximum of (1) the reported book value, (2) the initial cost of the property, or (3) the historic cost of the property including capital expenditures and tax depreciation (Ling et al., 2018a). As shown in Appendix Table 10, size weighted or adjusted cost weighted local beta generates very robust results.

6 Instead of market aggregate NCREIF return, we also use GDP return as a measure for the systematic return. As discussed in the robustness test section: the results remain robust.
} 
Table 1 Descriptive statistics for return data and firm characteristics

\begin{tabular}{lllll}
\hline & Mean & Std. Dev. & Max & Min \\
\hline $\begin{array}{llll}\text { Return data } \\
\quad\end{array}$ & & & & \\
$\quad$ REIT Return & 0.074 & 0.513 & 12.531 & -5.205 \\
$\quad$ NCREIF Return & 0.076 & 0.067 & 2.145 & -1.746 \\
Fama-French Factor & & & & \\
$\quad$ Market & 0.078 & 0.196 & 28.375 & -22.375 \\
SMB & 0.025 & 0.097 & 11.200 & -10.800 \\
HML & 0.029 & 0.104 & 12.075 & -10.550 \\
MOM & 0.047 & 0.083 & 11.300 & -7.575 \\
NAREIT index Return & 0.105 & 0.279 & 42.121 & -54.224 \\
Firm characteristics & & & & \\
Market Capitalization (Billion USD) & 2.639 & 3.796 & 26.068 & 0.000 \\
Price to Book Ratio & 2.044 & 1.185 & 7.439 & 0.017 \\
RE Investment Growth (\%) & 0.150 & 0.337 & 3.105 & -0.984 \\
Debt to Equity & 1.864 & 3.494 & 31.125 & 0.001 \\
MSA unemployment rate & 6.038 & 1.872 & 14.350 & 2.650 \\
HHI MSA & 0.199 & 0.236 & 1 & 0.013 \\
NOI (100 Million USD) & 23.653 & 19.439 & 338.454 & -0.031 \\
GA expenses (100 Million USD) & 9.712 & 1.435 & 13.194 & 3.526 \\
Density & 101 & 73 & 583 & 5 \\
\hline
\end{tabular}

area (CBSA) and Metropolitan statistical area (MSA) divisions since $1978 .{ }^{7}$ Those MSAs with return data for less than 10 quarters are excluded. However, there is a mismatch in the regions used in the two databases. SNL only records the MSA of each property, but NCREIF divides markets into CBSA and MSA divisions. Accordingly, we convert the local beta from MSA divisions to MSAs by calculating the MSA average local beta weighted by the number of NCREIF properties in each MSA division. As shown in Table 1, on average, direct real estate investments have an annual return of $8 \%$ and a standard deviation of $6 \%$. Compared to REIT returns, the reported returns of direct real estate investments are very stable with much lower volatility. ${ }^{8} r_{f, q}$ is the risk-free rate as measured by the yield on the 1-month Treasury bill. $M K T_{q}^{N P I}$ is aggregate NCREIF direct real estate returns in period $q$. It should be noted that by definition, for individual REITs, the local real estate market risk is non-diversifiable risk, as shown in Appendix 1. Even for REIT investors with diversified REIT portfolios, it is still a non-diversifiable risk, so it can be priced in the equity return.

\footnotetext{
${ }^{7}$ Alternatively, MSA beta can also be calculated using data from 1998 to 2015, which covers the same period as the REITs' return. The results based on MSA beta over the period from 1998 to 2015 are even stronger.

${ }^{8}$ The NPI returns are, of course, subject to appraisal smoothing effects, which are acknowledged and the issue is addressed in a later robustness test. .
} 
Table 2 Descriptive statistics for estimated beta

\begin{tabular}{llllr}
\hline & Mean & Std. Dev. & Max & Min \\
\hline MSA Beta & & & & \\
$\quad$ Market beta & 0.818 & 0.356 & 2.791 & -0.446 \\
Market beta_rolling window & 0.816 & 0.491 & 3.797 & -1.002 \\
Market beta_Leveraged Return & 0.840 & 0.387 & 2.003 & -0.655 \\
Market beta_De-smoothed Leveraged Return & 0.815 & 0.503 & 2.102 & -2.332 \\
Local Real Estate Market Beta & & & & \\
Local beta & 0.879 & 0.088 & 1.206 & 0.663 \\
Local beta_rolling window & 0.868 & 0.140 & 1.755 & 0.063 \\
$\quad$ Local beta_instrumented weights & 0.881 & 0.089 & 1.213 & 0.653 \\
Local Beta_Desmoothed Leveraged Return & 0.953 & 0.151 & 1.457 & 0.615 \\
\hline
\end{tabular}

The summary statistics of the estimated $\beta_{m}$ are reported in Table 2. $\beta_{m}$ has a mean of 0.818 and a standard deviation of 0.356 . Figure 1a plots the histogram of MSA betas. Most MSA betas are between 0.5 and 1.5. Albany-Schenectady Troy, NY, experienced the highest beta, over 2.5, which implies that the property markets there are very sensitive to aggregate real estate shocks. New York-Newark-Edison has the second-highest beta, amounting to 1.5. Three MSAs, Little Rock-North Little Rock, AR; Grand Rapids-Wyoming, MI and Scranton - Wilkes-Barre -Hazleton, PA, show a significant negative beta, over -0.3 . This implies that the real estate market there moves in the opposite direction from the national real estate market and therefore can counter-balance the national market. ${ }^{9}$ The geographic distribution of MSA betas is illustrated in Fig. 1b. The strength of the betas is represented by the colour and the size of the circles. The circle with the horizontal line pattern denotes a beta higher than 2 , the circle with the $\mathrm{X}$ pattern denotes an MSA beta between 1 and 2, the circle with the dot pattern denotes an MSA beta between 0 and 1 and the circle with the vertical line pattern denotes an MSA beta less than 0. The size of the dots is proportional to the absolute value of the MSA beta. As shown in Fig. 1-2, higher betas are concentrated in coastal areas, while most of the inland MSAs have the beta below 1. Obviously, coastal MSAs are more sensitive to aggregate real estate shocks. Among the 25 MSAs having a beta higher thanone, only three are inland. The distribution of the local betas largely coincides with measures of land regulatory strictness, for instance, the Wharton Residential Land Use Regulation Index (WRLURI). ${ }^{10}$ Gyourko et al. (2019) show that most restricted markets are situated along the northeast coast (from Boston down through Washington, D.C.) or the west coast

\footnotetext{
${ }^{9}$ Clearly these are small MSAs in terms of NCREIF holdings and hence there may be concerns about the robustness of such results and the practicality of investing in these markets.

${ }^{10}$ It should be noted that the land supply index is only for residential land, rather than the commercial land. Since only the residential land supply index is available, we use it as a proxy. We think that is reasonable to assume that if land use regulations (and topography) are tight for housing then they'll be tight for commercial real estate too.
} 


\section{a) Histogram}

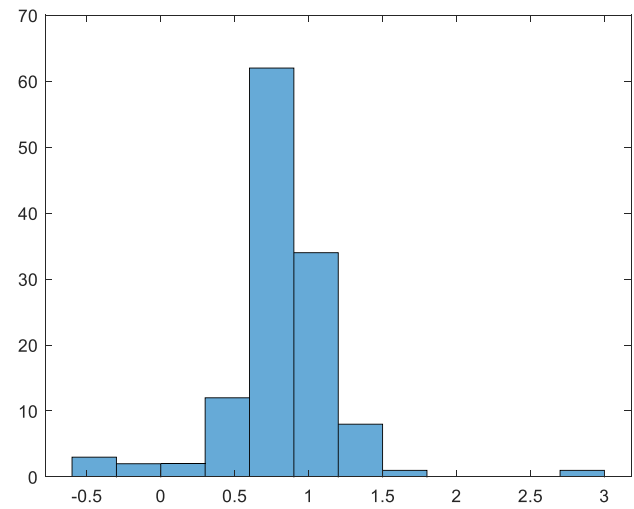

\section{b) Geographic Distribution}

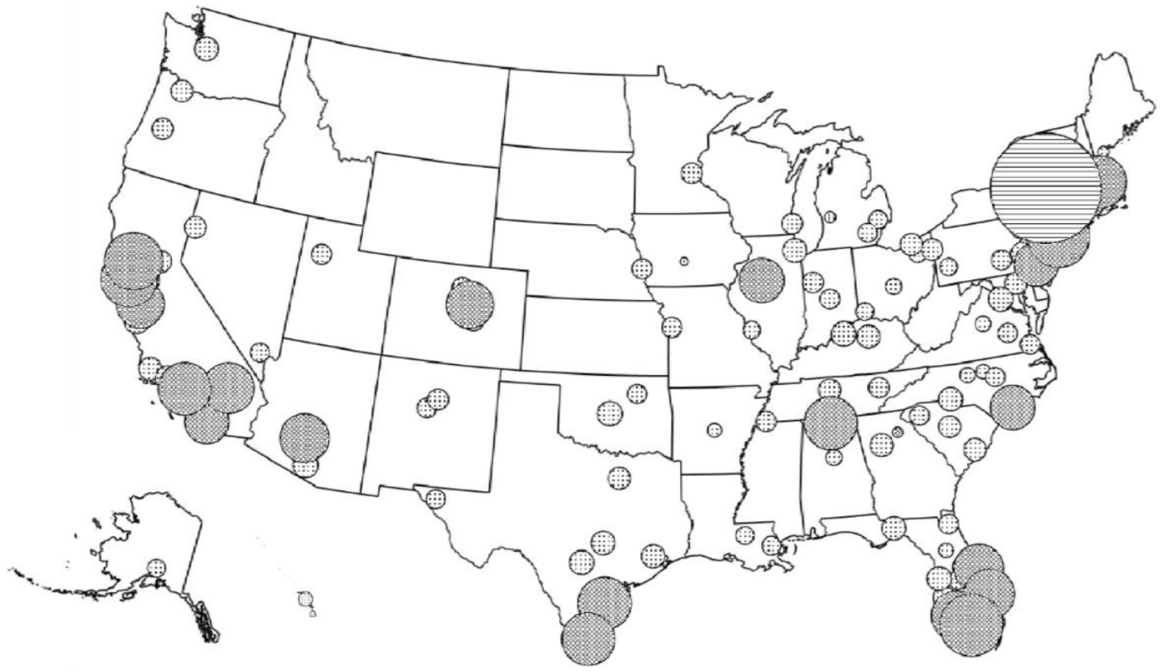

Fig. 1 Distribution of MSA betas. a: Histogram. Note: The figure plots the histogram distribution of MSA betas. b: Geographic Distribution. Note: The figure plots the geographic distribution of MSA betas. The circle with the horizontal lines denotes a beta higher than 2 , the circles with the crosses denote a beta between 1 and 2, the dotted circles denote a beta between 0 and 1 and the circles with vertical lines denote a beta less than 0 . The size of the circles is proportional to the absolute value of the MSA beta

of the country (Seattle, Portland (OR), San Francisco, and Los Angeles), whereas the most lightly regulated are among the group of larger metropolitan areas in the so-called Rust Belt region (e.g., Cleveland, OH, Grand Rapids, MI, Cincinnati, $\mathrm{OH}$, Detroit, MI, and St. Louis, MO).

Table 3 lists the MSAs with the lowest and highest betas, to shed more light on local betas. MSAs with the highest betas tend to experience higher property returns and larger standard deviation, as indicated by the significant positive 
a) Time Varying MSA betas

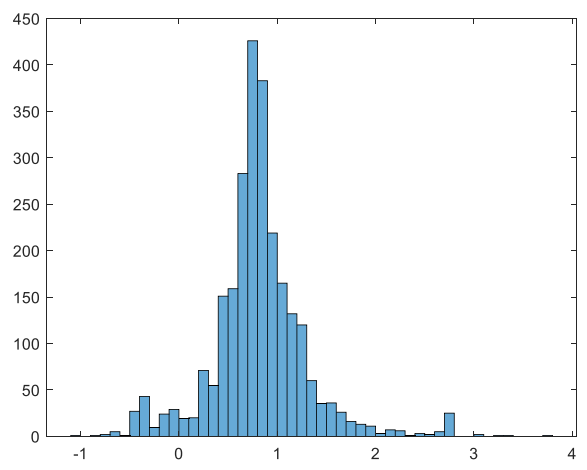

b) Leveraged betas

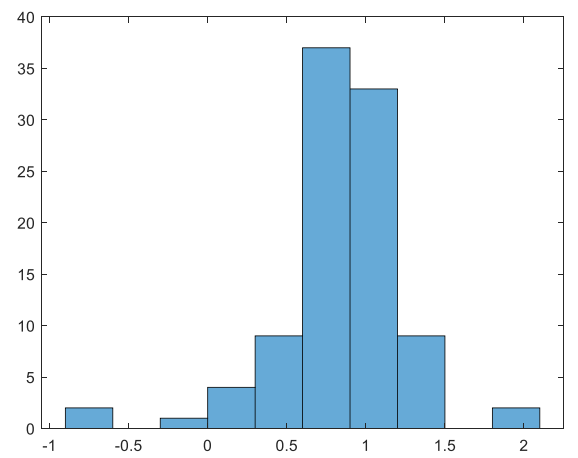

c) Leveraged and De-smoothed betas

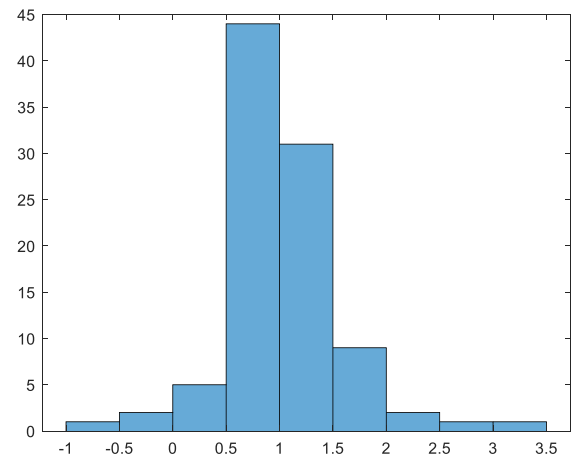

Fig. 2 Distribution of MSA betas. a: Time Varying MSA betas, b: Leveraged betas, c: Leveraged and De-smoothed betas. Note: The figure plots the distribution of MSA betas in the robustness test. Panel $\mathbf{a}$ is based on the time varying rolling window MSA betas. Panel $\mathbf{b}$ is leveraged NCREIF MSA returns and national returns. Panel $\mathbf{c}$ is based on the desmoothed leveraged NCREIF MSA returns and national returns

correlation coefficients between them. This is consistent with the theory that property investors require a higher expected return to compensate for taking more risks.

Interestingly, we do not find a significant positive relationship between the local betas and local economic conditions, such as average regional GDP growth rate, GDP growth volatility, and unemployment rate. Instead, the property market beta is more related to real estate market-related factors such as supply elasticity, market size, and liquidity. If we use the WRLURI as a proxy for supply elasticity, the property market beta has a significant positive correlation with the land regulatory strictness. In markets with inelastic supply, demand shock cannot be accommodated quickly due to a steep (short-run) supply curve, and we would expect a more severe cyclical movement of the price. Focusing on the housing market, Glaeser et al. (2008) also find a more pronounced housing cycle in inelastically-supplied markets. 


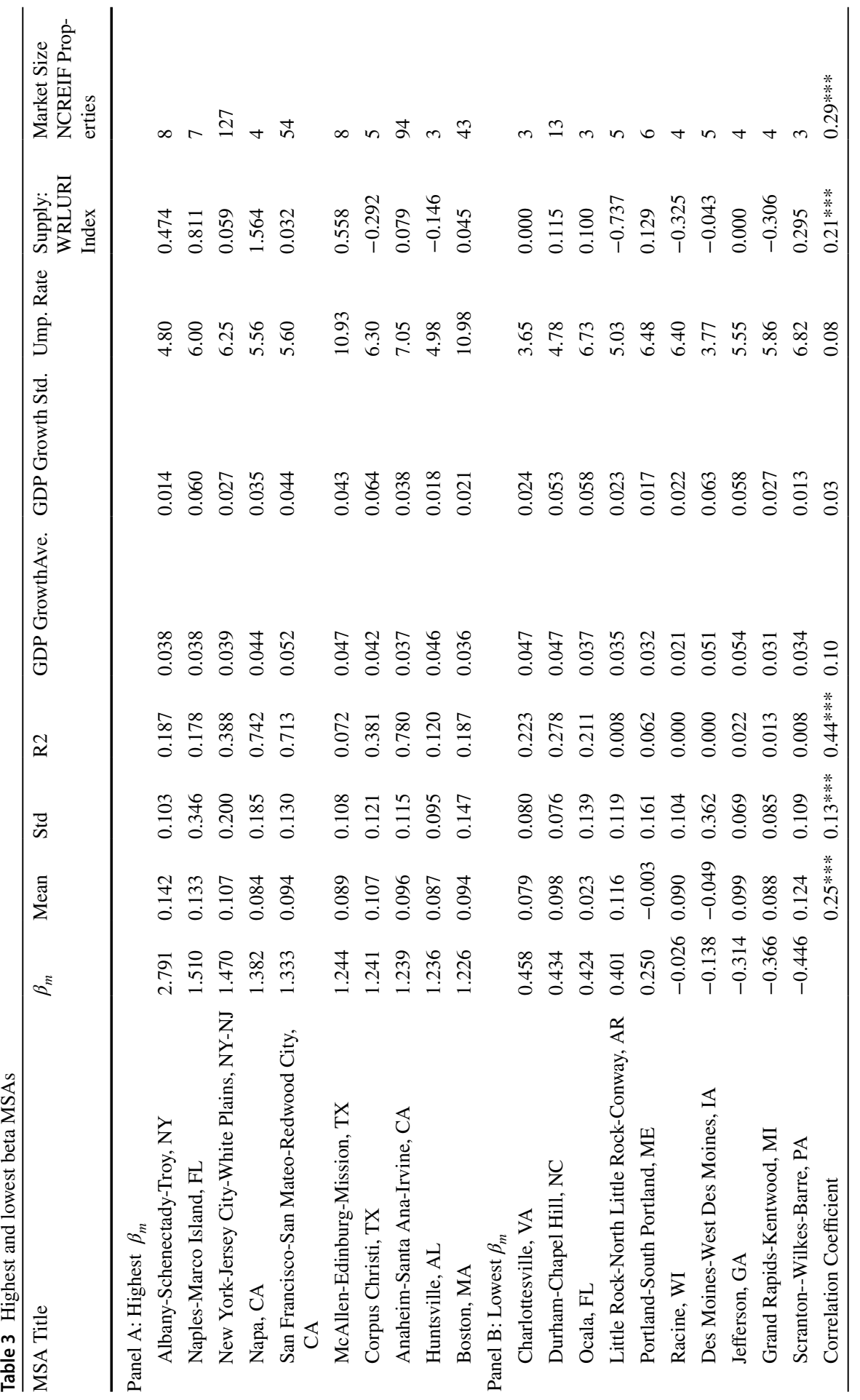




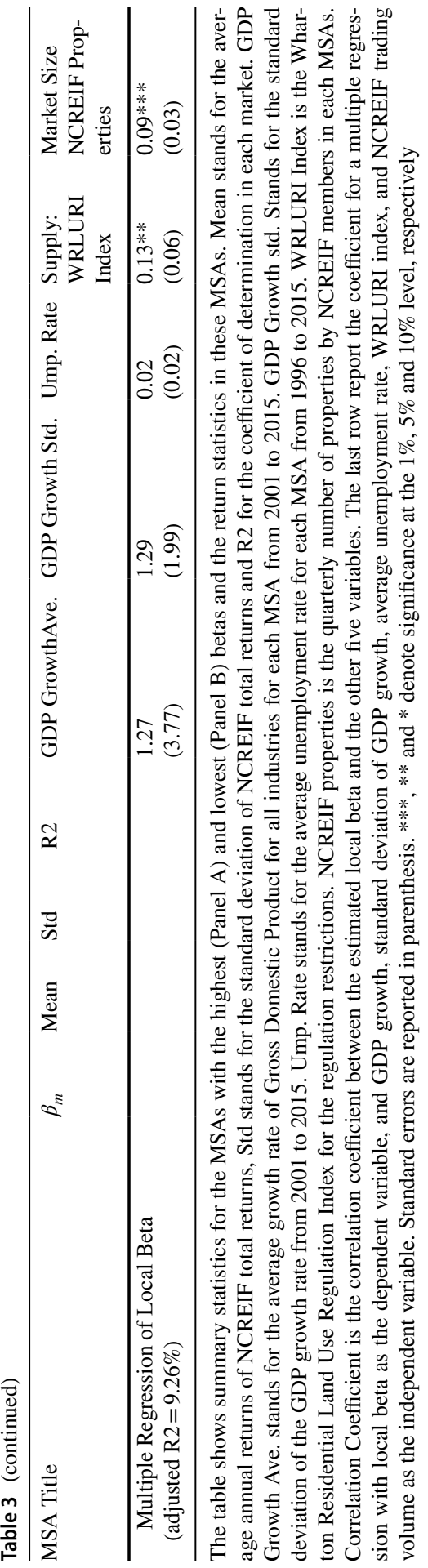


If we use the NCREIF number of properties as a proxy for real estate market size, ${ }^{11}$ the MSA beta is also significantly positively related to market size. Larger markets tend to be more prone to national shocks, consistent with the previous finding that larger markets have higher volatility in aggregate (Drennan \& Kelly, 2011). There are a number of possible explanations. First, one channel might be liquidity. Much prior literature has documented a positive relationship between trading volume and return volatility (Brailsford, 1996; Foster \& Viswanathan, 1993). In a larger real estate market, trading volume tends to be higher, which may lead to higher price volatility (Li \& Zhu, 2021). Second, it may be explained by an information effect. In markets with fewer sales, signals can be noisier. As a result, appraisal error or nonadjustment of values in response to national shocks in smaller markets may be more likely. Third, the larger markets will have a greater influence on the aggregate market index since the aggregate market index is weighted by the market value. This can also be confirmed by the higher $\mathrm{R}^{2}$ in larger markets. The national aggregate market index explains higher return variations in larger markets. Fourth, properties in large real estate markets are more likely to be occupied by national and international firms (Lizieri, 2009) and/or owned by national and international real estate investors (Lizieri \& Mekic, 2018; Zhu \& Lizieri, 2021), who are more prone to national macro shocks rather than the more idiosyncratic effects found in local markets.

Based on $\beta_{m}$ and $w_{m . i, t}$, we calculate the local beta for each REIT based on their property portfolio. The estimated local beta for each REIT is summarised in Table 3. The average $\beta_{i, t}^{\text {LREM }}$ is 0.88 and the standard deviation is quite small, only 0.09 . The maximum local beta is 1.21 , and the minimum is 0.66 . Obviously, the firm level local beta has a much smaller standard deviation than the MSA betas, since most REITs have well-diversified property portfolios. On average, properties in each REIT are distributed in 33 MSAs, with a minimum of one MSA and a maximum of 370 .

\section{Firm Characteristics}

Data concerning individual company characteristics are collected from SNL Financial. The returns and market capitalisation data are from Thomson Reuters DataStream. We collect data for all available U.S. listed real estate companies ${ }^{12}$ locational information on assets between 1998 and 2015, a total of 202 real estate firms. Overall, $76 \%$ of properties in each firm are located in the 144 MSAs with NCREIF NPI property returns. 145 firms have over $70 \%$ of properties located in those 144 MSAs. Our results are based on these 145 firms. Due to missing values in other explanatory variables, the final sample consists of 99 REITs.

\footnotetext{
${ }^{11}$ Using the NCREIF number of sold properties as a proxy for the market size generate the robust results.

12 All firms are REITs in 2015. But SNL keeps firm information before the firm was converted to REIT. If we exclude the observations before the REIT status was established, the results remain completely robust.
} 
Table 2 summarizes the firm characteristics of the real estate companies, averaged across time, from 1998 to 2015, and across the 99 companies. The average annual return across all companies is $7.4 \%$, with a standard deviation of $51 \%$. We also see a large variation across the size of the companies in terms of market capitalisation, with the highest being $\$ 26$ billion and the lowest, $\$ 0.35$ million. On average, a company has a market capitalisation of $\$ 2627$ million. The average market to book ratio $(\mathrm{M} / \mathrm{B})$ ratio is 2.04 . The average debt to equity (D/E) ratio is 1.86 . The average real estate investment growth rate is $0.15 \%$, with a maximum of $3.11 \%$ and a minimum of $-0.98 \%$. We also account for market power or market concertation using the Herfindahl-Hirschman Index (HHI) at the MSA level. The HHI measures the geographic concentration of properties of one firm across the MSAs:

$$
H H I_{i t}=\sum_{l=1}^{L}\left(\frac{P_{t, i, l}}{N_{t, i}}\right)^{2},
$$

where $P_{t, i, l}$ is the number of properties of firm $i$ with $n=1,2, \ldots, N$ that locate in MSA $l$ with $l=1,2, \ldots, L$ in year $t$. The HHI ranges from close to 0 to 1 . If HHI has a value of one, it means that all properties of the firm are located in the same MSA. The lower the HHI value, the less concentrated are the firm's properties across the MSAs.

\section{Stock Market beta}

Local beta reflects the risk exposure to the underlying real estate markets. As REITs are listed on the stock market, equity market risk exposure must also be considered. Equity market risk exposure is measured using a standard four factor model, with the sensitivity of a REIT's return to stock market return calculated as the conditional factor loading $\left(\beta_{i, t}^{\text {stock}}\right)$ for firm $i$ and year $t$ :

$$
r_{i, t, d}^{R E I T}-r_{f, t, d}=\alpha_{i, t}+\beta_{i, t}^{\text {stock }} M K T_{t, d}^{\text {stock }}+\beta_{i, t}^{S M B} S M B_{t, d}+\beta_{i, t}^{H M L} H M L_{t, d}+\beta_{i, t}^{M O M} M O M_{t, d}+\varepsilon_{i, t, d},
$$

where $r_{i, t, d}^{R E I T}$ is the daily return in day $d$ in year $t$ for firm i and $r_{f, t}$ is the corresponding risk-free rate as measured by the yield on the 1-month Treasury bill. The factors comprise a US market return index (MKT), the difference between the returns on diversified portfolios of small stocks and big stocks (SMB) and the difference between the returns on diversified portfolios of high $\mathrm{M} / \mathrm{B}$ (value) stocks, low $\mathrm{M} / \mathrm{B}$ (growth) stocks (HML), and the difference between the monthly returns on diversified portfolios of winners and losers over the past year (MOM). For consistency with prior research, the factors are obtained from Ken French's website. As shown in Table 2, REITs have been more volatile than general stock markets over the period from 1998 to 2015, and REIT investors also received a slightly higher return as compared to general stock investors. 


\section{Empirical Results}

\section{Cross-Sectional Fama-MacBeth Regression Results}

A Fama-MacBeth cross-sectional regression is conducted to identify whether local real estate market risks have been priced in REIT equity returns. The Fama-MacBeth regression is run in two stages. In the first stage, for each year of our sample period, we estimate the following cross-sectional regression:

$$
r_{i, t}^{R E I T}-r_{f, t}=c_{0}+\gamma^{\mathrm{RE} \mathrm{local}} \beta_{i, t-1}^{\mathrm{LREM}}+\gamma^{\text {Stock Mrkt }} \beta_{i, t-1}^{\text {stock }}+\sum_{k=1}^{K} c_{i, k} X_{k, i, t}+e_{i, t},
$$

where $r_{i, t}^{R E I R}-r_{f, t}$ is the firm's annual excess return with respect to the yield on the 1-month Treasury bill. $X_{m, i, t}$ is one of the following K firm characteristics: the change in SIZE, defined as the log-differenced firm's aggregate market capitalization; M/B, defined as the market value of assets divided by the book value of assets; $\mathrm{LEV}$, defined as total debt divided by the book value of equity; and RE Invest, the real estate investment growth. We also include property type dummy variables. In the second stage, we use the time series of the regression coefficients and test if the average coefficient is significantly different from zero. To take into account serial correlation in the coefficient estimates, we compute Newey-West standard errors

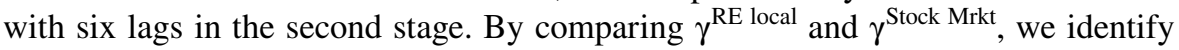
changes in the REIT price triggered by the systematic risks from direct real estate market and equity markets.

Table 4 presents the main results starting with Model 3 (in Models 1 and 2, only local beta or stock beta is included). In Model 4, instead of contemporaneous control variables $\left(X_{k, i, t}\right)$, lagged control variables are used $\left(X_{k, i, t-1}\right)$. In Model 5 and 6 , more control variables are included. The results confirm that, with the increase in local real estate market risks, REIT returns increase significantly. The coefficient for lagged local beta remains significant in all specifications. Investors require a higher return to compensate for a higher exposure to riskier local property markets. Exposure to a more cyclical real estate market (high beta markets) increases the perceived risk of firms' equity and,therefore, investors require a higher reward to compensate for the additional risk.

Regarding the dual nature of REITs, the sensitivity to real estate and stock market risk can be compared based on the size of the corresponding coefficient. Economically, a one standard deviation change in the local beta will result in a $1.6 \%$ increase in REIT returns (Model 3). ${ }^{13}$ A one standard deviation change in stock beta is related to a $2.5 \%$ increase in REIT returns, ${ }^{14}$ which is some 1.5 times higher than the sensitivity to real estate betas. This finding is consistent with the previous REIT literature. In the short term, the stock market plays a more dominant role in REIT

\footnotetext{
13 The economic impact is calculated as the coefficient (0.1781) multiplied by the standard deviation of the local beta, which is 0.088 .

14 The economic impact is calculated as the coefficient $(0.0555)$ multiplied by the standard deviation of the stock beta, which is 0.443 .
} 
Table 4 Local beta and firm returns

\begin{tabular}{|c|c|c|c|c|c|c|}
\hline & Model 1: & Model 2: & Model 3: & Model 4: & Model 5: & Model 6: \\
\hline \multirow{2}{*}{$\beta_{\text {firm }, t-1}^{L R E M}$} & $0.1584 * *$ & & $0.1781 * * *$ & $0.1761 * * *$ & $0.1268 *$ & $0.3188 * * *$ \\
\hline & $(0.0638)$ & & $(0.0670)$ & $(0.0407)$ & $(0.0655)$ & $(0.0945)$ \\
\hline \multirow{2}{*}{$\beta_{f i r m, t-1}^{\text {Stock Mrkt }}$} & & $0.0538 * *$ & $0.0555^{*}$ & $0.0732 * * *$ & 0.0566 & $0.0676^{* * *}$ \\
\hline & & $(0.0218)$ & $(0.0291)$ & $(0.0217)$ & $(0.0362)$ & $(0.0209)$ \\
\hline \multirow[t]{2}{*}{$r_{i, t-1}^{R E I T}$} & $-0.1365^{* * *}$ & $-0.0617 * *$ & $-0.1409 * * *$ & -0.0830 & $-0.1043^{* *}$ & $-0.1419 * * *$ \\
\hline & $(0.0344)$ & $(0.0278)$ & $(0.0374)$ & $(0.1541)$ & $(0.0521)$ & $(0.0387)$ \\
\hline \multirow[t]{2}{*}{ Change in Size } & $5.1137 * * *$ & $4.7762 * * *$ & $5.2923 * * *$ & 0.1497 & $5.0010 * * *$ & $4.9892 * * *$ \\
\hline & $(0.8293)$ & $(0.8201)$ & $(0.8351)$ & $(0.6190)$ & $(1.0031)$ & $(0.7569)$ \\
\hline \multirow[t]{2}{*}{ Market to Book } & $0.0329 * * *$ & $0.0348 * * *$ & $0.0310 * * *$ & -0.0001 & $0.0293 * * *$ & $0.0305 * * *$ \\
\hline & $(0.0066)$ & $(0.0069)$ & $(0.0068)$ & $(0.0187)$ & $(0.0064)$ & $(0.0066)$ \\
\hline \multirow[t]{2}{*}{ RE Investment Growth } & -0.0733 & $-0.1312 * * *$ & $-0.0803 *$ & -0.0014 & $-0.0817 * *$ & -0.0753 \\
\hline & $(0.0482)$ & $(0.0332)$ & $(0.0417)$ & $(0.0209)$ & $(0.0402)$ & $(0.0535)$ \\
\hline \multirow[t]{2}{*}{ Debt to Equity } & -0.0025 & $-0.0019^{*}$ & -0.0022 & 0.0016 & -0.0018 & -0.0023 \\
\hline & $(0.0019)$ & $(0.0011)$ & $(0.0024)$ & $(0.0027)$ & $(0.0018)$ & $(0.0027)$ \\
\hline \multirow[t]{2}{*}{$\beta_{i, t-1}^{S M B}$} & & & & & 0.0178 & \\
\hline & & & & & $(0.0396)$ & \\
\hline \multirow{2}{*}{$\beta_{i, t-1}^{H M L}$} & & & & & -0.0292 & \\
\hline & & & & & $(0.0392)$ & \\
\hline \multirow[t]{2}{*}{$\beta_{i, t-1}^{M O M}$} & & & & & -0.0158 & \\
\hline & & & & & $(0.0447)$ & \\
\hline \multirow{2}{*}{$\beta_{i}^{\text {head }}$} & & & & & & -0.0005 \\
\hline & & & & & & $(0.0467)$ \\
\hline \multirow[t]{2}{*}{ MSA_HP } & & & & & & -0.9048 \\
\hline & & & & & & $(3.1419)$ \\
\hline \multirow[t]{2}{*}{ MSA_Ump } & & & & & & -0.0153 \\
\hline & & & & & & $(0.0107)$ \\
\hline \multirow[t]{2}{*}{ MSA_GDP } & & & & & & 0.2523 \\
\hline & & & & & & $(0.9645)$ \\
\hline \multirow[t]{2}{*}{ NOI } & & & & & & -0.0002 \\
\hline & & & & & & $(0.0007)$ \\
\hline \multirow[t]{2}{*}{ GA expenses } & & & & & & -0.0587 \\
\hline & & & & & & $(0.0584)$ \\
\hline \multirow[t]{2}{*}{ Property Density } & & & & & & -0.0123 \\
\hline & & & & & & $(0.0291)$ \\
\hline Property Type Dummy & Yes & Yes & Yes & Yes & Yes & Yes \\
\hline No. of obs & 1171 & 1711 & 1170 & 1084 & 1170 & 1156 \\
\hline Adj. R2 & 0.8379 & 0.8153 & 0.8472 & 0.8566 & 0.9134 & 0.8656 \\
\hline
\end{tabular}

This table reports the results of Fama-MacBeth cross-sectional regression. The dependent variable is the annual excess return netting of the T-bill rate. $r_{\text {firm, } t-1}^{R E I T}$ is the lagged return. $\beta_{\text {firm,t-1 }}^{L R E M}$ stands for the lagged local beta for firm i. $\beta_{\text {firm, } t-1}^{\text {Stock }}$ is for the lagged stock market beta. $\beta_{i, t-1}^{S M B}, \beta_{i, t-1}^{H M L}$, and $\beta_{i, t-1}^{M O M}$ are the beta for Fama-French factors. Control variables include previous returns, change in market value, debt to equity ratio, market to book ratio, real estate investment growth and property type dummy. Standard errors are reported in parenthesis. $* * *, * *$ and $*$ denote significance at the $1 \%, 5 \%$ and $10 \%$ level, respectively 
performance. However, in the following section, we show that this conclusion may not be applicable to all REITs. The sensitivity to real estate market risk depends on the diversification strategy of REITs.

The regression results for the control variables are consistent with previous literature (Table 4, Model 3). Firms with increasing size and a higher M/B ratio have higher returns. Real estate investment growth has a negative coefficient; this can be explained by the fact that high investment growth may result in higher management costs and therefore reduce the equity returns of REITs.

In Model 5, risk exposure to other Fama-French-Carhart factors are also included. As shown in Table 4, the coefficient for local beta remains significant. As high exposure to risky real estate markets may have an impact on operating cash flows and management costs, the relationship between local beta and REIT excess returns may actually be caused by the underlying property cash flows. Therefore, in Model 6, we include Net Operating Income (NOI) and G\&A expenses as additional control variables. Furthermore, firm equity return may be affected by the local risk in the headquarter of the firm. The MSA beta where the REIT's headquarter locates is also included as an additional control variable to investigate whether the riskiness of the local property market is transmitted into REIT performance via the location of the headquarter or the location of the assets. We also use the residential market performance to proxy for the local demand and supply for real estate and even the credit supply in the local markets, as the recent housing boom is believed to closely relate to the excess credit supply to the real estate markets in general. We also consider the impact from local business conditions, measured by the GDP growth rate and unemployment rate. Additionally, local beta may also be strongly related to property density. In most downtown areas, the market would be more liquid. Therefore, concerns could arise that the local real estate market risks may only capture the impact of investing in downtown or suburban areas - the density of the location, rather than the liquidity risk. We, therefore, also control the density of properties in Model 6. We add another control variable - the average number of properties held by any other REIT located within a $5 \mathrm{~km}$ radius of each individual property. ${ }^{15}$ Overall, the results remain robust. The coefficient for local beta remains significant throughout.

\section{Geographic Diversification and Local Betas}

We further test the impact of geographic diversification. We split the sample into well- and less-diversified REITs according to the geographic location of property portfolios: $50 \%$ of the firm with more concentrated assets and $50 \%$ of firms with more diversified assets according to their HHI values. The results for these two groups of firms are reported in Model 8 and 9 in Table 5. For the 50\% of REITs with more diversified assets, the coefficient for $\beta_{i, t}^{\mathrm{LREM}}$ is insignificant.

\footnotetext{
15 We count the number of properties surrounding each property held by a REIT, and then calculate the average number for that REIT, given the total number of properties held by that REIT. It should be noted that, since we only have the information about the properties held by REITs, the density is measured by the properties held by REITs, not the full property universe.
} 


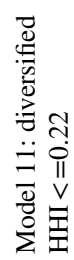

莺

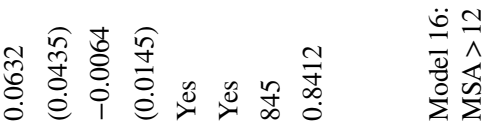

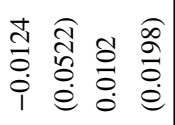

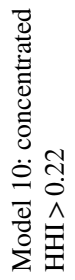
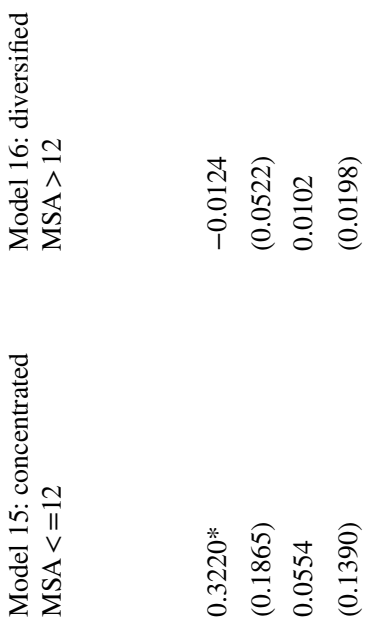

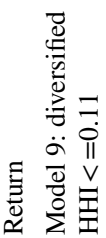

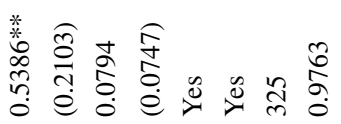

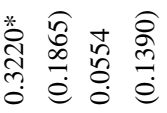

胥

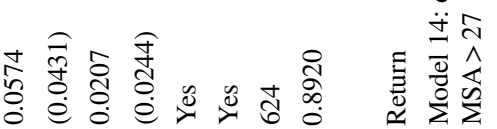

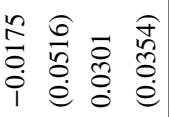

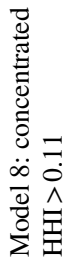

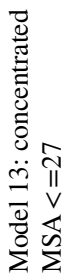

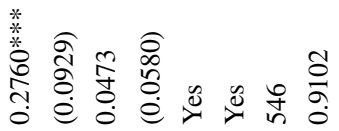

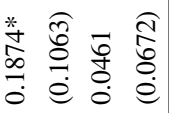

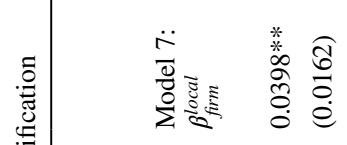

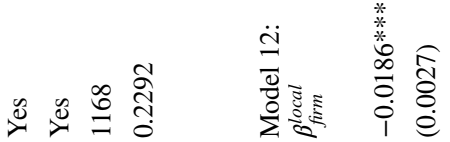

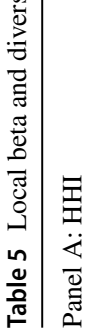

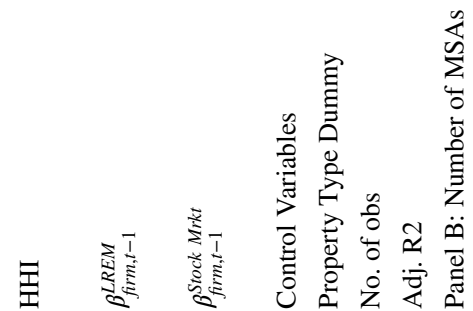

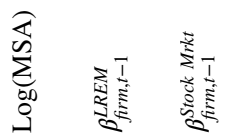




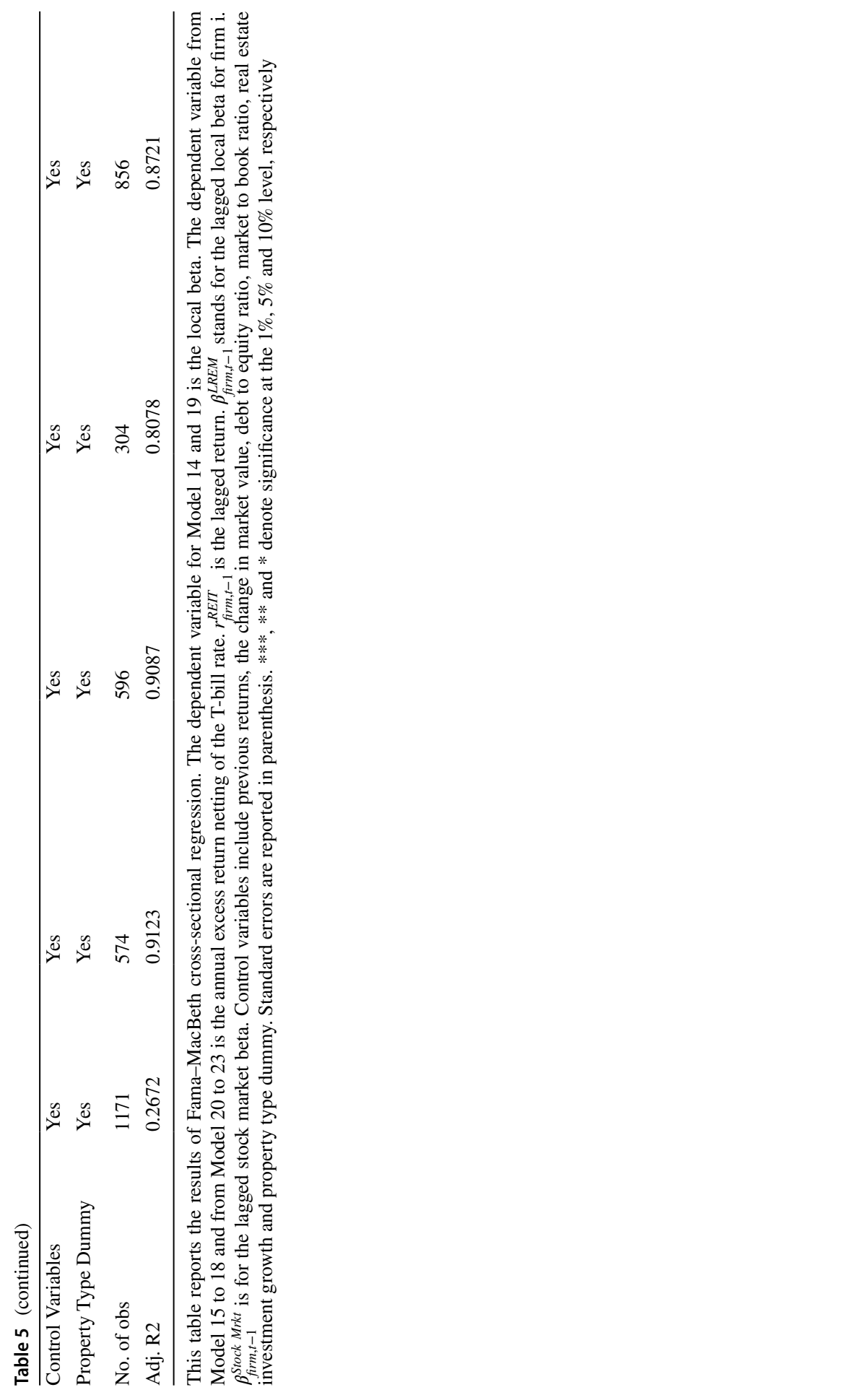


Real estate risks are not priced in the equity return, implying that investors may decide that the local real estate market risks can be ignored due to diversification. But for the $50 \%$ of REITs with less diversified assets, the coefficient for $\beta_{i, t}^{\mathrm{LREM}}$ rises to 0.3344 . We further split the sample into $33 \%$ of the most concentrated firms and the rest, as shown in Model 10 and 11. With the increase in the concentration threshold, the sensitivity to local real estate market risks increases further to 0.4953 . This implies that a one standard deviation increase in the local real estate market risks will be related to up to a $4.7 \%$ increase in the equity return. Overall, geographic diversification helps REITs to reduce their sensitivity to real estate market risks. However, for sensitivity to stock market risk, we do not find a similar pattern. Using the number of MSAs where properties are located generates similar results. With the increase in the number of MSAs, local real estate market risks decrease significantly. When a REIT holds properties spread over 13 or more MSAs, local real estate markets are not priced in REIT equity returns.

A higher sensitivity of more concentrated REITs to the national shocks can be partly explained by the fact that concentrated REITs are more likely to invest in larger markets, such as New York or San Francisco. For instance, for REITs with an HHI concertation over $90 \%$, on average, over $96 \%$ of their properties located in MSAs with a beta larger than one, whereas for the remaining REITs, only $25 \%$ of their assets located in these MSAs. Concentrated REITs tend to have high exposure to high beta areas. Therefore, the value of its underlying assets would respond more strongly to aggregate shocks than diversified REITs, which have low exposure to the high beta areas. As a result, investors would perceive a higher equity risk for firms in high beta areas than for firms in low beta areas and demand a higher reward for taking that risk. Although the local real estate market risks are, by definition, systematic, they cannot be diversified away in a REIT portfolio and hence are priced, as with equity market risk sensitivity, investors may still perceive REITs with geographically diversified portfolios to be less prone to those local market shocks and so do not demand a return premium.

Additionally, the insignificant relationship between local beta and the excess return for diversified REITs can also be explained by the dependency of the riskreturn relationship on market conditions. Focusing on the stock market, Fletcher (2000), Huang and Hueng (2008), Tang and Shum (2003), and many others show a positive risk-return relationship in up markets (positive market excess returns) and a negative relationship in down markets (negative market excess returns). As a result, the overall relationship between stock beta and equity return can become insignificant. This argument can also explain our finding for diversified REITs. With diversification, REITs may have exposure to markets with both positive and negative excess returns. As a result, the relationship between the local real estate market risks and equity returns can be less positive than those REITs focusing on the markets with a high local beta and thereby positive excess returns. 


\section{Robustness Checks}

\section{Self-Selection}

We further consider the situation that $w_{m . i, t}$ may be affected by the potential selfselection in some REITs having a bias for less risky and more liquid real estate markets. We use the distance to headquarters as the instrument for $w_{m . i, t}$. Based on home bias theory, the distance of assets to the headquarters can be a good predictor for the firm's asset allocation. Market participants often choose local investment to reduce information asymmetry in opaque information environments (Garmaise \& Moskowitz, 2004). Ling et al. (2018b) also show that managers overweight asset allocations to their local market. Therefore, the distance of properties to the headquarters can be a relevant instrument. For each firm, we regress the proportion of properties in MSA $m$ on the distance to the headquarters:

$$
w_{m . i, t}=a_{i}+b_{i} \ln D_{m, i, t}+e_{t}
$$

where $D_{m, i, t}$ is the average distance of properties located in the MSA $m$ to the headquarters of REIT $i$. For instance, if two properties are located in MSA $m, D_{m, i, t}$ is the average distance of these two properties to the headquarters of the firm. For the estimation of Eq. (6), we require that the firm has investments on at least three different MSAs. For firms with properties located in only one or two MSAs, we use the observed weights. The estimated $b_{i}$ is illustrated in Fig. 3a. Most of the coefficients are negative. The average coefficient is -0.056 and the average $\mathrm{T}$ statistic is -1.96 . So the instrumented weight is calculated as $\hat{w}_{m . i, t}=\hat{a}_{i}+\hat{b}_{i} \ln D_{m, i, t}$ and the local beta is calculated as $\beta_{i, t}^{\mathrm{LREM}}=\sum_{m=1}^{M} \hat{w}_{m . i, t} \beta_{m}$. The estimated results based on instrumented weights are reported in Table 6, Model 17. The coefficient rises to 0.22.

However, previous literature shows that REIT performance can be affected by the geographic diversification of underlying assets or the share of the assets locating in the home MSAs, which may challenge the exogeneity of the instrument. Therefore, the share of home assets (Model 18) and the Herfindal asset concentration indicator (Model 19) are also controlled. We argue that this instrument is conditionally exogenous given control of the diversification strategy. A further concern could be that firms' performance can also be affected by being local or dispersed. For instance, Garcia and Norli (2012) find that local firms have lower investor recognition, which implies a higher required return in their equity. It should be noted that we are not using the absolute distance, but the relative distance of each property to the headquarters, as the instrument, separately for each firm. Therefore, this instrument is not affected by whether the firm is a local firm or a dispersed firm. It is independent of the average distance of the assets to the headquarter. If firm A has all assets in one distant MSA, and if firm B has all assets in its headquarter MSAs, the weights for both firms are 1, although firm A is a dispersed firm and firm B is a local firm.

Although we are able to argue the exogeneity of distance to the MSA real estate market performance, the relevance of the instrument needs may not be satisfied. We follow the classical $\mathrm{F}$ test for the validity of the instrument. However, in our paper, we run the first stage regression (Eq. 6) for each firm in each year. So in total, we 
have 1618 regressions in the first stage. The $\mathrm{p}$ value of the $\mathrm{F}$ statistic in each first stage regression is plotted out in Fig. $3 b$. The $\mathrm{x}$-axis is the p value of the test, and the $y$-axis is the frequency of each $p$ value. Around $43 \%$ of the regressions have a $p$ value lower than $10 \%$. In order to make sure of the relevance of the instrument, we exclude those firm-year observations with an insignificant F-test and construct $\hat{w}_{m, i, t}^{\text {sig }}$ using only observations with significant F-tests. The results are reported in Table 6 , Model 20. Due to the reduction in the number of $\hat{w}_{m, i, t}^{\text {sig }}$ decreases, the total number of observations in the second stage (Model 20) is reduced by nearly half. However, even with this conservative adjustment, the coefficient remains significant.

Since the number of observations decreases by nearly half, we further test whether the remaining sample is still representative using a Heckman correction. We first investigate the probability of surviving (Eq. 7), and then include the Inverse Mills ratio of the estimated probability as an additional regressor to correct for potential selection bias (Eq. 8):

$$
\begin{gathered}
\operatorname{Prob}_{\mathrm{i}, \mathrm{t}}=c+d X_{i, t}+\gamma_{i}+\delta_{t}+u_{i, t}, \\
y_{i, t}=\alpha \mathrm{T}_{i, t-1}+\beta X_{i, t}+\theta \text { Mîll }_{\mathrm{i}, \mathrm{t}}+\gamma_{i}+\delta_{t}+e_{i, t},
\end{gathered}
$$

The dependent variable for Eq. (8) is a dummy variable with the value of one when the F test is significant at the $10 \%$ level, and zero when the F test is insignificant. In other words, a significant $\mathrm{F}$ test means that the distance to the headquarters is a valid instrument for this firm at this period. This REIT is more likely to allocate assets in its local markets. The results of Eq. 8 is shown in Table 6, Model 21. The coefficient for the local beta again remains significant and of comparable magnitude to the other specifications.

\section{Time-Varying MSA Beta}

The MSA beta based on Eq. 2 is constant over time, which allows us to capture the average cyclicality of each property market. We also investigate a time-varying local beta using a 30 quarter rolling window, to allow for possible structural changes in property market volatility.

$$
r_{m,(\mathrm{q}-30, \mathrm{q})}^{N P I}-r_{f,(\mathrm{q}-30, \mathrm{q})}=\alpha_{m, q}+\beta_{m, q}\left(M K T_{(\mathrm{q}-30, \mathrm{q})}^{N P I}-r_{f,(\mathrm{q}-30, \mathrm{q})}\right)+\varepsilon_{m, q} .
$$

where $r_{m,(\mathrm{q}-30, \mathrm{q})}^{N P I}$ is the NPI return over the past 30 quarters at period $q$ in MSA $m$. Based on the leveraged NPI returns, the mean of $\beta_{m, q}$ slightly increases to 0.822 and the standard deviation grows to 0.564 . The larger standard deviation in the MSA beta could be due to the smaller number of observations in the regression. As shown in Fig. 2-a, the beta distribution shows obviously heavier tails. We then calculate the local beta based on the rolling MSA betas. However, given the fact that some MSAs have NPI returns for less than 30 quarters, many missing values appear. When there is missing value in the rolling window MSA beta, we use the average MSA beta as a substitute. The summary statistics are reported in Table 2; the local beta with rolling 


\section{a) Coefficient of Distance}

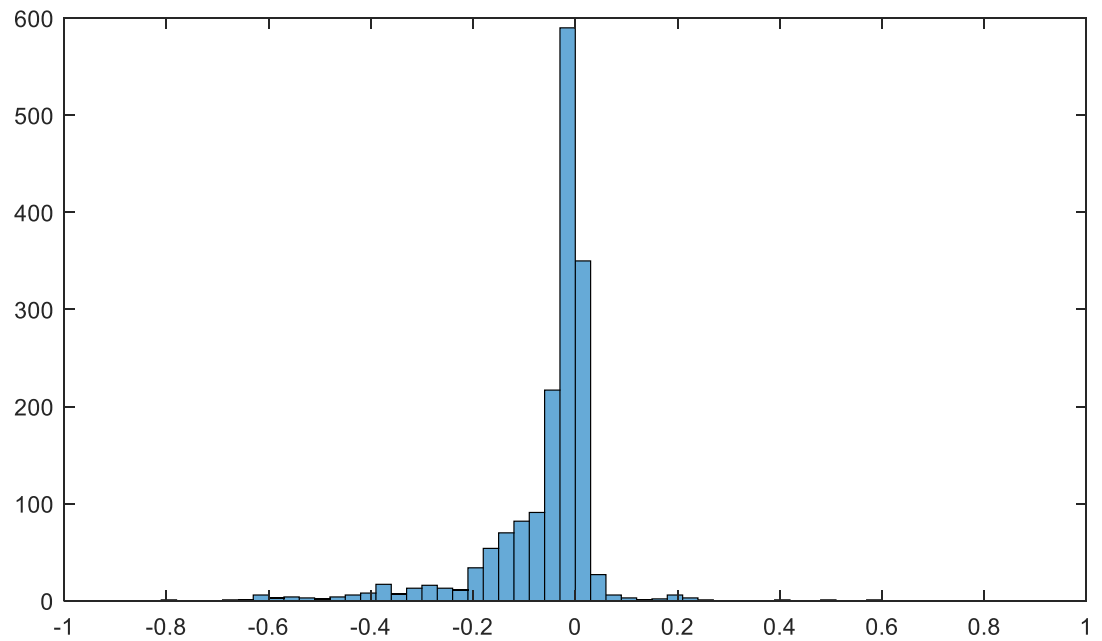

\section{b) F test for the Relevance of Distance}

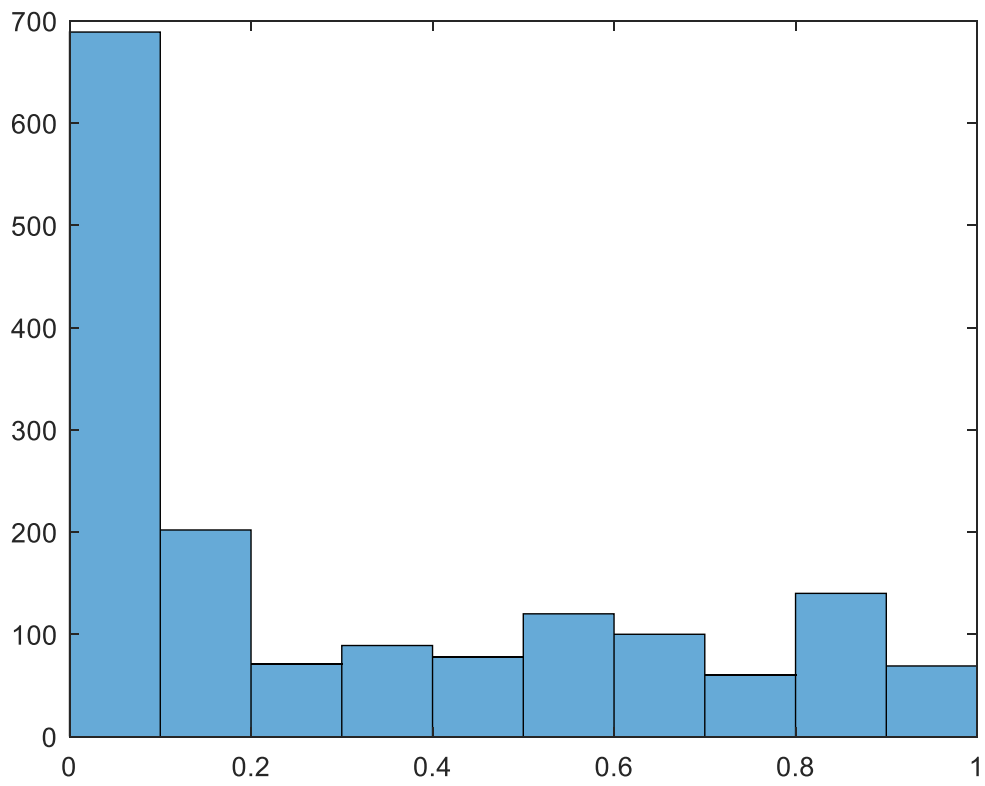

Fig. 3 Distance as the Instrument. a Coefficient of Distance. Note: The figure plots the distribution of the coefficient for the distance in the auxiliary regression for the instrumented proportion of properties in each MSAs. The proportion of properties for a certain MSA is regressed on the average distance of all properties held this firm located in a certain MSA to the headquarter of the firm. The regression is run separately for each firm. b F test for the Relevance of Distance. Note: This graph shows F statistics for the relevance test of the instrument. The $\mathrm{x}$-axis is the $\mathrm{p}$ value of the test, and $\mathrm{y}$-axis is the frequency of each $\mathrm{p}$ value. Among the 1618 year-firm observations, 689 (42\%) have the p value lower than $10 \%$ 
Table 6 Robustness checks: self selection

\begin{tabular}{|c|c|c|c|c|c|}
\hline & $\begin{array}{l}\text { Model 17: } \\
\text { Instrumented } \\
\text { weights }\end{array}$ & $\begin{array}{l}\text { Model 18: } \\
\text { Instrumented } \\
\text { weights }\end{array}$ & $\begin{array}{l}\text { Model 19: } \\
\text { Instrumented } \\
\text { weights }\end{array}$ & $\begin{array}{l}\text { Model 20: } \\
\text { Instrumented } \\
\text { weights_SigFtest }\end{array}$ & $\begin{array}{l}\text { Model 21: } \\
\text { Instrumented } \\
\text { weights_Heckman }\end{array}$ \\
\hline$\beta_{\text {firm }, t-1}^{L R E M}$ & $\begin{array}{l}0.2469 * * * \\
(0.0588)\end{array}$ & $\begin{array}{l}0.2417 * * * \\
(0.0660)\end{array}$ & $\begin{array}{l}0.2510 * * * \\
(0.0542)\end{array}$ & $\begin{array}{l}0.1964 * * * \\
(0.0646)\end{array}$ & $\begin{array}{l}0.1197 * * * \\
(0.0353)\end{array}$ \\
\hline$\beta_{\text {firm, } t-1}^{\text {Stock Mrkt }}$ & $\begin{array}{l}0.0674 * * * \\
(0.0227)\end{array}$ & $\begin{array}{l}0.0663 * * * \\
(0.0208)\end{array}$ & $\begin{array}{l}0.0669 * * * \\
(0.0198)\end{array}$ & $\begin{array}{l}0.0397 \\
(0.0553)\end{array}$ & $\begin{array}{l}0.0430 \\
(0.0731)\end{array}$ \\
\hline$r_{\text {firm }, t-1}$ & $\begin{array}{l}-0.0810 * * \\
(0.0342)\end{array}$ & $\begin{array}{l}-0.0788^{* *} \\
(0.0348)\end{array}$ & $\begin{array}{l}-0.0802^{* *} \\
(0.0344)\end{array}$ & $\begin{array}{l}-0.0658 \\
(0.0959)\end{array}$ & $\begin{array}{l}0.0053 \\
(0.0963)\end{array}$ \\
\hline Change in Size & $\begin{array}{l}5.1104 * * * \\
(0.8391)\end{array}$ & $\begin{array}{l}5.0726 * * * \\
(0.8338)\end{array}$ & $\begin{array}{l}5.1190 * * * \\
(0.8184)\end{array}$ & $\begin{array}{l}5.7351 * * * \\
(1.4489)\end{array}$ & $\begin{array}{l}5.8840 * * * \\
(1.8552)\end{array}$ \\
\hline Market to Book & $\begin{array}{l}0.0353 * * * \\
(0.0064)\end{array}$ & $\begin{array}{l}0.0347 * * * \\
(0.0075)\end{array}$ & $\begin{array}{l}0.0346^{* * *} \\
(0.0073)\end{array}$ & $\begin{array}{l}0.0363 * * * \\
(0.0095)\end{array}$ & $\begin{array}{l}0.0538 * * * \\
(0.0130)\end{array}$ \\
\hline $\begin{array}{l}\text { RE Invest. } \\
\text { Growth }\end{array}$ & $\begin{array}{l}-0.0652 \\
(0.0443)\end{array}$ & $\begin{array}{l}-0.0756^{*} \\
(0.0455)\end{array}$ & $\begin{array}{l}-0.0739 \\
(0.0483)\end{array}$ & $\begin{array}{l}-0.0630 \\
(0.0451)\end{array}$ & $\begin{array}{l}0.0375 \\
(0.1163)\end{array}$ \\
\hline Debt to Equity & $\begin{array}{l}-0.0004 \\
(0.0018)\end{array}$ & $\begin{array}{l}-0.0006 \\
(0.0018)\end{array}$ & $\begin{array}{l}0.0005 \\
(0.0025)\end{array}$ & $\begin{array}{l}-0.0001 \\
(0.0040)\end{array}$ & $\begin{array}{l}-0.0253 * * * \\
(0.0083)\end{array}$ \\
\hline Home Assets & & $\begin{array}{l}0.0050 \\
(0.0374)\end{array}$ & & $\begin{array}{l}0.0266 \\
(0.0186)\end{array}$ & \\
\hline HHI & & & $\begin{array}{l}-0.0025 \\
(0.0416)\end{array}$ & & \\
\hline Prob. & & & & & $\begin{array}{l}-1.4096^{*} \\
(0.8100)\end{array}$ \\
\hline $\begin{array}{l}\text { Property Type } \\
\text { Dummy }\end{array}$ & Yes & Yes & Yes & Yes & Yes \\
\hline No. of obs & 1284 & 1283 & 1281 & 682 & 660 \\
\hline Adj. R2 & 0.8434 & 0.8459 & 0.8465 & 0.7540 & 0.8750 \\
\hline
\end{tabular}

This table reports the results of Fama-MacBeth cross-sectional regression. The dependent variable is the annual excess return netting of the T-bill rate. $r_{\text {firm,t }-1}^{R E I T}$ is the lagged return. $\beta_{\text {firm,t }-1}^{L R E M}$ stands for the lagged local beta for firm i. $\beta_{\text {firm,t-1 }}^{\text {Stock }}$ is for the lagged stock market beta. Control variables include previous returns, the change in market value, debt to equity ratio, market to book ratio, real estate investment growth and property type dummy. Standard errors are reported in parenthesis. $* * *, * *$ and $*$ denote significance at the $1 \%, 5 \%$ and $10 \%$ level, respectively

MSA beta has a very similar mean but a much larger standard deviation. The Fama Macbeth regression results are reported in Table 7 . The results are robust with the local beta coefficient remaining significant with a value of 0.16 (Model 22).

\section{Property Sector}

Our MSA beta is calculated using properties in all sectors. However, different property sectors may be subject to different levels of risk. The local beta should match REITs against the relevant NPI sectors. The NPI NCREIF Property Index includes Apartment, Hotel, Industrial, Office, Retail, and other properties. We acknowledge 
that our local beta using all NPI properties is not an ideal measurement for the different cyclicality across property sectors.

Therefore, we try further robustness tests. First, we split the sectors into two broad categories: commercial and residential. Ideally, a more detailed sector split should be applied. However, further categorization generates too many missing observations. For example, only 14 MSAs have sufficient hotel property returns to calculate the local hotel beta. As a result, we only split the property types into two categories. We then calculate the beta separately for each sector:

$$
\begin{gathered}
r_{m, q}^{N P I, \text { Residential }}-r_{f, q}=\alpha_{m}+\beta_{m}^{\text {residential }}\left(M K T_{q}^{N P I, \text { Residential }}-r_{f, q}\right)+\varepsilon_{m, q} \\
r_{m, q}^{N P I, \text { Commercial }}-r_{f, q}=\alpha_{m}+\beta_{m}^{\text {commercial }}\left(M K T_{q}^{N P I, \text { Commercial }}-r_{f, q}\right)+\varepsilon_{m, q} \\
\beta_{i, t}^{\text {local }}=\sum_{m=1}^{M} w_{m . i, t}^{\text {residential }} \beta_{m}^{\text {residential }}+\sum_{m=1}^{M} w_{m . i, t}^{\text {commercial }} \beta_{m}^{\text {commercial }}
\end{gathered}
$$

We report the results based on two-sector MSA beta in Table 7 Model 23, which again are robust, albeit with a fall in the magnitude of the local beta coefficient.

Alternatively, we exclude specialized REITs, including Office, Retail, Residential, Industry, and Hotel. Only 46 REITs are left. Since diversified REITs hold different types of properties, our local beta should have a smaller measurement error for them. As expected, the local beta coefficient rises in magnitude.

\section{Leverage and Valuation Smoothing}

The validity of the NCREIF NPI index is sometimes questioned. One concern is about leverage. REIT performance indices embed the impact of leverage, but NCREIF NPI returns are reported on an unlevered basis. Hoesli and Oikarinen (2012) show that the magnitude of leverage can affect the mean and the volatility of REITs. In an additional robustness check, we use the leveraged NPI NCREIF returns. However, not all properties in the NCREIF database report leverage, so the leveraged return covers much fewer properties in each MSA and only 109 MSAs have NCREIF leveraged return data over 10 quarters. So $\beta_{m}^{L E V}$ and $\beta_{i, t}^{L E V, \text { local }}$ is calculated based on a smaller sample.

Based on the leveraged NPI returns, the mean of $\beta_{m}^{L E V}$ rises to 0.860 and the standard deviation grows to 0.564. Both are higher than using unleveraged total returns (Table 2). Baton Rouge, LA, MSA even has a very negative $\beta_{m}$ of -3.5 . The reason is that when the total return of unleveraged projects is lower than the interest rate, leverage actually has a negative impact on the leveraged return. The overall distribution of $\beta_{m}^{L E V}$ is shown in Fig. 3. With a higher and more volatile $\beta_{m}^{L E V}$, the real estate risk exposure of REITs also increases. The average $\beta_{i, t}^{L E V, l o c a l}$ slightly rises to 0.840 and the standard deviation increases to 0.387 . As leverage influences financial risk, the real estate risk taken by REITs is amplified by the use of leverage. 


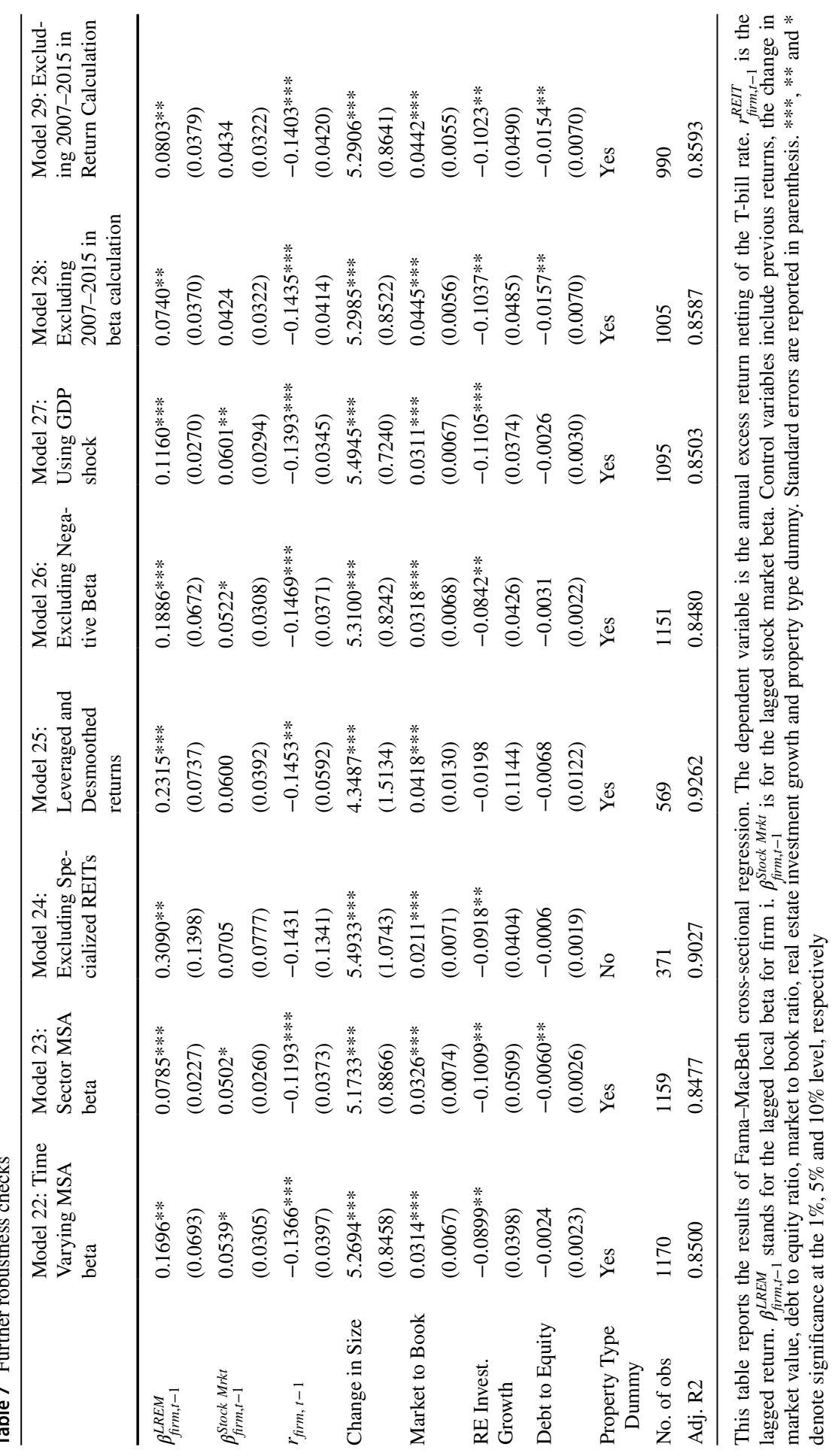


Appraisal smoothing is another concern. NCREIF returns are appraisal-based, which may lead to smoothing if appraisers anchor on prior values. To extract the true returns, a desmoothing procedure must be used (Geltner et al., 2003; Lizieri et al., 2012). The simplest is a first-order autoregressive reverse filter. Equation (2) provides the smoothed total returns for direct real estate investment. Now we look at the leveraged NPI return as a combination of the current true real estate return and a lagged component for the prior index value:

$$
r_{m, t}^{L e v}=\left(1-\gamma_{m}\right) r_{m, t}^{\text {True }}+\gamma_{\mathrm{m}} r_{m, t-1}^{\text {Lev }}
$$

where $r_{m, t}^{\text {True }}$ denotes the true underlying real estate returns. $\gamma_{m}$ is the smoothing parameter for MSA $m$ and can be calculated as the first-order autoregressive coefficient for the NPI returns. By re-arranging Eq. (13), $r_{m, t}^{\text {True }}$ can be derived as:

$$
r_{m, t}^{T r u e}=\frac{r_{m, t}^{L e v}-\gamma r_{m, t-1}^{L e v}}{1-\gamma} .
$$

Based on $r_{m, t}^{\text {True }}, \beta_{m}^{\text {DeSm,Lev }} \mathrm{s}$ and the corresponding $\beta_{i, t}^{\text {DeSm,Lev,local }}$ for REITs are reestimated based on Eq. (15) and (16):

$$
\begin{gathered}
r_{m, t}^{\text {True }}-r_{f, t}=\alpha_{m}+\beta_{m}^{\text {DeSm,Lev }}\left(M K T_{t}^{\text {True }}-r_{f, t}\right)+\varepsilon_{m, t} . \\
\beta_{i, t}^{\text {DeSm,Lev,local }}=\sum_{m=1}^{M} w_{m . i, t} \beta_{m}^{\text {DeSm,Lev }} .
\end{gathered}
$$

After de-smoothing the return series, $\beta_{m}^{\text {DeSm }}$ decreases slightly, with a mean of 0.815 and standard deviation of 0.502 . The Fama-MacBeth regression results are quite robust. The coefficient for real estate local beta remains very robust (Table 7 Model 24).

\section{Other Robustness Tests}

In our local beta calculation, we have some MSAs with a significant negative beta, whose inclusion would be controversial given standard expectations. The negative beta might be caused by the short return periods and/or the small sample included in the NCREIF NPI database for these MSAs. In other words, the estimated beta for these MSAs might not be reliable. So, we exclude MSAs with a negative beta and re-run the regression. The results are presented in Table 7, Model 25. The coefficient for local beta remains robust.

Instead of using the national aggregated real estate returns, we also use aggregated GDP change to calculate local beta. In this way, the local beta reflects the sensitivity of local real estate market performance on national economic shocks. The results are reported in Table 7 , Model 26, which is robust.

A further concern could be the coincidence of returns and local beta, particularly during the period 2009 to 2014. Over this period, REIT market capitalisation increases at nearly $19 \%$ per annum, so there is a massive increase in listed real estate equity. Over the same time, price growth is more than $9 \%$ p.a., which is higher than 
the long run average. It may be that the local beta increases over that period (for example, via more exposure to gateway cities), coinciding with higher returns and thus pushing up the explanatory power of the local beta.

We employ two robustness checks to address this issue. First, we exclude the period 2007-2015 when we calculate the MSA beta (Eq. 2). The local beta is now estimated without any influence of the volatile period on property market performance. We then estimate the relationship between REIT return and local beta. Second, we still calculate MSA beta (Eq. 2) using the full sample, but we only include the before-crisis period (1999-2006) when we calculate the impact of local beta on REIT returns (Eq. 5). As shown in Table 7, Model 27 and 28, the influence of local beta on REIT returns becomes weaker in both tests, but remains significant.

We also apply previous robustness tests on the two groups of REITs (Appendix Table 11). The results are very robust. With the increase in the concentration of assets, REITs become more vulnerable to local real estate market risks. $33 \%$ of the most concentrated firms have the highest sensitivity to local beta.

\section{Portfolio Construction and Non-market Returns}

We examine the non-market returns (or alphas) on REITs portfolios using an asset pricing model:

$$
r_{p, t}-r_{f, t}=\alpha_{p}+\beta_{p, 1} M K T_{t}+\beta_{p, 2} S M B_{t}+\beta_{p, 3} H M L_{t}+\beta_{p, 4} M O M_{t}+\beta_{p, 5} L I Q_{t}+\beta_{p, 6} R E_{t}+\varepsilon_{p, t},
$$

where $r_{p, t}$ is the equally-weighted monthly return on a given portfolio and $r_{f, t}$ is the corresponding risk-free rate as measured by the yield on the 1-month Treasury bill. We use two sets of factors. The first set are the two Fama-French factors (SMB and HML), the Carhart momentum factor (MOM) and the Pastor and Stambaugh liquidity factor (LIQ), in addition to the stock market return index (MKT). The second set is real estate factors to control for real estate market exposure. For this purpose, we also include listed real estate returns (NAREIT). ${ }^{16}$

The regressions are based on portfolios of REITs' monthly returns between 1998 and 2015. The baseline results present four sorted portfolios, from the bottom 25th percentile of REITs with the highest local real estate market risks and the upper 25 th percentile of firms with the lowest local real estate market risks. Table 8 reports alpha and beta for each portfolio based on Eq. (17). Among the six factors, the stock market factor has the highest sensitivity. The beta coefficient is close to one. Size factor and high minus low factor also play a role in the portfolio returns. The real estate factor, NAREIT returns, plays a limited role. This might be caused by the fact that NAREIT returns are highly correlated with the stock market return.

\footnotetext{
16 Alternatively, we also used the NCRIEF total return indicator as an additional measure for real estate market performance; the results remain robust. However, the beta for NCREIF total return index is significantly negative, which might be caused by the multicollinearity between NCRIEF returns, NAREIT returns and stock market returns.
} 
Although none of the alphas of the four portfolios is significant, the alpha for the portfolio based on taking the long position in REITs with the highest local beta and taking the short position of REITs with the lowest local risk is significant. If investors perceive a higher risk in REITs subject to higher real estate risks, we would expect a higher return on portfolios with a high exposure relative to those with low exposure. In other words, portfolio managers with an information advantage are able to "buy low" before positive information has been incorporated into asset valuations and "sell high" before negative information has been fully reflected into falling asset prices. Firms with the 25 th quantile highest local beta experience an average nearly monthly non-market return of $-0.02 \%$. Firms with the 25 th quantile lowest local beta experience an average return of $-0.43 \%$. This implies 41 basis point monthly ( $4.9 \%$ annually) return difference, which is statistically and economically significant.

We further double-sort the portfolios according to diversification and local real estate market risks. REITs are first grouped into 50\% REITs with more concentrated assets (50\% highest HHI or lowest number of MSAs) and the rest. We then construct four equally-weighted portfolios for each group of REITs, from the bottom 25 th percentile of firms with the highest local real estate market risks to the upper 25 th percentile of firms with the lowest local real estate market risks. As shown in Table 9, a significant difference in the alpha between a portfolio with the highest and lowest exposure to local real estate market risks only occurs in REITs with more concentrated assets, confirming the regression results in the previous section. For REITs with geographically well-diversified assets, there is no significant difference

Table 8 Portfolios based on local beta

\begin{tabular}{|c|c|c|c|c|c|c|c|c|}
\hline Portfolio & Alpha & MR & SMB & HML & MOM & LIQ & $\mathrm{RE}$ & $\mathrm{R} 2$ \\
\hline \multicolumn{9}{|c|}{ Panel A Portfolio formed based on Local real estate market risk } \\
\hline \multirow[t]{3}{*}{ Highest } & $\begin{array}{l}-0.0002 \\
(-0.0489)\end{array}$ & $\begin{array}{l}0.9251 * * * \\
(10.0399)\end{array}$ & $\begin{array}{l}0.5059 \text { *** } \\
(4.1383)\end{array}$ & $\begin{array}{l}0.4846^{* * *} \\
(4.0026)\end{array}$ & $\begin{array}{l}0.4083 * * * \\
(2.5399)\end{array}$ & $\begin{array}{l}-0.0911 \\
(-0.9774)\end{array}$ & $\begin{array}{l}0.0864 * * \\
(2.0415)\end{array}$ & 0.4869 \\
\hline & $\begin{array}{l}-0.0019 \\
(-0.5287)\end{array}$ & $\begin{array}{l}1.0051 * * * \\
(10.9329)\end{array}$ & $\begin{array}{l}0.5621 \text { *** } \\
(4.6085)\end{array}$ & $\begin{array}{l}0.4458 * * * \\
(3.6904)\end{array}$ & $\begin{array}{l}0.5592 * * * \\
(3.4861)\end{array}$ & $\begin{array}{l}-0.1728^{*} \\
(-1.8576)\end{array}$ & $\begin{array}{l}0.0373 \\
(0.8824)\end{array}$ & 0.5052 \\
\hline & $\begin{array}{l}-0.0041 \\
(-1.0913)\end{array}$ & $\begin{array}{l}0.9792 * * * \\
(9.9500)\end{array}$ & $\begin{array}{l}0.6024 * * * \\
(4.6140)\end{array}$ & $\begin{array}{l}0.5316^{* * *} \\
(4.1104)\end{array}$ & $\begin{array}{c}0.3359 * \\
(1.9565)\end{array}$ & $\begin{array}{l}-0.1217 \\
(-1.2222)\end{array}$ & $\begin{array}{c}0.0774 * \\
(1.7118)\end{array}$ & 0.4994 \\
\hline Lowest & $\begin{array}{l}-0.0043 \\
(-1.0687)\end{array}$ & $\begin{array}{l}0.9998 * * * \\
(9.5495)\end{array}$ & $\begin{array}{l}0.5338^{* * *} \\
(3.8432)\end{array}$ & $\begin{array}{l}0.3696 * * * \\
(2.6869)\end{array}$ & $\begin{array}{l}0.6337 * * * \\
(3.4693)\end{array}$ & $\begin{array}{l}-0.1777^{*} \\
(-1.6772)\end{array}$ & $\begin{array}{l}0.0828^{*} \\
(1.7205)\end{array}$ & 0.4240 \\
\hline \multicolumn{9}{|c|}{ Panel B: Portfolio long in firms with the highest local beta and short in firms with the lowest local beta } \\
\hline $\begin{array}{r}\text { Long H } \\
\text { short }\end{array}$ & $0.0041^{* *}$ & -0.0747 & -0.0279 & $0.1150^{*}$ & $-0.2254 * * *$ & 0.0866 & 0.0037 & 0.0449 \\
\hline $\begin{array}{l}\text { L Port- } \\
\text { folio }\end{array}$ & $(2.0231)$ & $(-1.4067)$ & $(-0.3964)$ & $(1.6489)$ & $(-2.4337)$ & $(1.6115)$ & $(0.1505)$ & \\
\hline
\end{tabular}

This table presents factor model results of portfolios sorted into 4 groups from the bottom to the top 25 th percentile based on the local beta. Alpha stands for non-market return. MR stands for the return factor, SMB stands for the size factor, HML stands for the book-to-market value factor, MOM stands for the momentum factor and LIQ stands for the liquidity factor. RE stands for the listed real estate returns. The portfolios are constructed based on monthly data. The T-statistic is reported in parentheses. ***,** and * denote significance at the $1 \%, 5 \%$ and $10 \%$ level, respectively 
Table 9 Portfolios based on local beta__ Diversification

\begin{tabular}{|c|c|c|c|c|c|c|}
\hline \multicolumn{7}{|c|}{ Panel A: HHI } \\
\hline & Local Beta & High & & & Low & H-L \\
\hline \multirow[t]{6}{*}{ HHI } & High & 0.0010 & -0.0029 & $-0.0137 * * *$ & $-0.0069^{*}$ & $0.0148 * * *$ \\
\hline & & $(0.29)$ & $(-0.81)$ & $(-2.31)$ & $(-1.76)$ & (3.44) \\
\hline & Low & -0.0073 & -0.0035 & -0.0036 & -0.0063 & -0.0037 \\
\hline & & $(-1.58)$ & $(-0.81)$ & $(-0.87)$ & $(-1.23)$ & $(-1.56)$ \\
\hline & H-L & $0.0084 * * *$ & 0.0006 & $-0.0101 * * *$ & -0.0007 & \\
\hline & & (3.16) & $(0.18)$ & $(-2.59)$ & $(-0.24)$ & \\
\hline \multicolumn{7}{|c|}{ Panel B: Number of MSAs } \\
\hline & Local Beta & High & & & Low & H-L \\
\hline \multirow{6}{*}{$\begin{array}{l}\text { Num } \\
\text { MSA }\end{array}$} & High & -0.0012 & -0.0040 & -0.0032 & -0.0068 & 0.0021 \\
\hline & & $(-0.28)$ & $(-0.71)$ & $(-0.69)$ & $(-1.23)$ & $(0.54)$ \\
\hline & Low & 0.0002 & -0.0015 & -0.0068 & -0.0053 & $0.0070^{*}$ \\
\hline & & $(0.04)$ & $(-0.36)$ & $(-1.26)$ & $(-1.11)$ & $(1.90)$ \\
\hline & H-L & -0.0013 & -0.0025 & 0.0036 & -0.0016 & \\
\hline & & $(-0.29)$ & $(-0.62)$ & (1.09) & $(-0.63)$ & \\
\hline
\end{tabular}

This table presents the factor model results of portfolios sorted into 8 groups from the bottom to the top 25th percentile based on the local beta and from the bottom to the top half REITs based on diversification. Alpha stands for non-market return. MR stands for the return factor, SMB stands for the size factor, HML stands for the book-to-market value factor, MOM stands for the momentum factor and LIQ stands for the liquidity factor. RE stands for the listed real estate returns. The portfolios are constructed based on monthly data. The T-statistic is reported in parentheses. $* * *, * *$ and $*$ denote significance at the $1 \%$, $5 \%$ and $10 \%$ level, respectively

in alpha. Local real estate market risks are priced in REIT returns, but only for REITs with concentrated assets. For the 50\% REITs with the highest HHI and the $50 \%$ lowest local beta show an average non-market return of $-0.69 \%$ p.m., which is statistically significant. The difference in the alphas rises to $1.48 \%$ percent p.m. (ca. $17.7 \%$ p.a.).

\section{Conclusion}

This paper studies the role of geography on equity performance from the point of local real estate market risks. For a firm with high exposure to risky real estate markets, the value of its underlying assets would respond more strongly to the aggregate shock than a firm with low exposure to risky markets. Therefore, the equity return of this firm would be higher, as investors would require a higher reward due to the perceived higher equity risk. The local real estate market risk is measured by local beta, which reflects the systematic risk of the underlying real estate markets where properties are located. The empirical results confirm a higher equity return for a firm with a higher local real estate market risk, mainly for firms with concentrated assets. On average, a one standard deviation increase in the local beta will result in a $1.6 \%$ increase in REIT equity returns. But for REITs with more 
diversified assets, the relationship between REIT returns and local beta becomes insignificant. The results remain robust when the issues concerning self-selection, leverage and valuation smoothing are corrected.

This paper has several implications. First, it helps real estate investors, pension funds, and multi-asset managers to characterise the nature of risk/return of REITs. REITs show much lower sensitivity to stock market risks and a more positive sensitivity to local real estate risks as compared to general industrial firms. As a result, REIT returns would respond positively to local shocks, while the equity returns of general industrial firms would not react to the real estate shocks. Therefore, given the different responses to the real estate risks, REITs can be considered as an alternative investment vehicle to general stocks in multi-asset portfolios.

Although U.S. REITs are characterized by geographical well-diversified, investors should be aware that local real estate market risk has still been priced in REIT returns, as the local beta is a non-diversifiable risk. In other words, local real estate market risks will not be diversified by holding REITs with geographically overlapped assets, by holding REITs focusing merely on large markets, or in high beta markets. However, investors can optimise the mix of REITs according to their exposure to risky real estate markets using a "smart local beta" strategy. An investment strategy which sells REITs with high exposure to high beta areas and buys high exposure to low beta areas can earn a non-market return of nearly $4.9 \%$ per year.

Furthermore, by touching on the local versus diversified debate, our research can also help individual REITs to understand the costs and benefits of being local. The empirical study shows that geographic diversification can limit the exposure to high risky real estate markets. One would thus expect lower equity returns due to reduced local real estate market risks and, thereby, reduced equity risk. For $33 \%$ of the most concentrated REITs, a one standard deviation increase in the local real estate market risks will be related to a $4.7 \%$ increase in REIT returns and, by implication, in the required cost of equity. Furthermore, a 'native' geographic diversification strategy may not successfully reduce the real estate market risks. Limiting the exposure to high risky real estate market is necessary for REITs to reduce the equity risk.

\section{Appendix}

\section{Appendix 1: Diversification Nature of Local Real Estate Market Risks}

We assume REIT $i$ has properties in M MSAs. The local real estate market beta for MSA $m$ is set as $\beta_{m}^{M S A}$, and the portfolio weight in MSA $m$ is $w_{i, m}^{M S A}$. The variance of the property portfolio will be

$$
\operatorname{var}\left[\sum_{m=1}^{M} w_{i, m}^{M S A} \beta_{m}^{M S A}\left(r_{\text {Nation, },}^{N P I}-r_{f}\right)\right]=\sum_{m=1}^{M}\left(w_{i, m}^{M S A} \beta_{m}^{M S A}\right)^{2} \sigma_{R E}^{2}+\sum_{m=1}^{M} \sum_{n=1}^{M-1} w_{i, m}^{M S A} w_{i, n}^{M S A} \beta_{m}^{M S A} \beta_{n}^{M S A} \sigma_{R E}^{2}
$$

where $r_{\text {Nation,t }}^{N P I}$ is the return of property investment at the national level. $\sigma_{R E}^{2}$ is the variance of the aggregated property market returns. If we assume the firm has equal weights in each MSA, we will have $w_{i, m}^{M S A}=\frac{1}{M}$, and if we define that $\bar{\beta}=\frac{1}{M} \sum_{m=1}^{M} \beta_{m}^{M S A}$, we have 
Table 10 Alternative estimate of local beta

\begin{tabular}{|c|c|c|}
\hline & $\begin{array}{l}\text { Model A1: } \\
\text { Size weighted }\end{array}$ & $\begin{array}{l}\text { Model A2: } \\
\text { Adjusted cost weighted }\end{array}$ \\
\hline \multirow{2}{*}{$\beta_{\text {firm }, t-1}^{L R E M}$} & $0.1149 * * *$ & $0.0949 * *$ \\
\hline & $(0.0158)$ & $(0.0370)$ \\
\hline \multirow{2}{*}{$\beta_{\text {firm }, t-1}^{\text {Stock Mrkt }}$} & 0.0313 & 0.0031 \\
\hline & $(0.0277)$ & $(0.0422)$ \\
\hline \multirow{2}{*}{$r_{i, t-1}^{R E I T}$} & $-0.1063 * *$ & $-0.1307 * * *$ \\
\hline & $(0.0523)$ & $(0.0407)$ \\
\hline \multirow[t]{2}{*}{ Change in Size } & $4.6235 * * *$ & $4.7106^{* * *}$ \\
\hline & $(1.5499)$ & $(1.2419)$ \\
\hline \multirow[t]{2}{*}{ Market to Book } & $0.0439 * * *$ & $0.0415 * * *$ \\
\hline & $(0.0047)$ & $(0.0052)$ \\
\hline \multirow[t]{2}{*}{ RE Investment Growth } & $-0.1140 * * *$ & $-0.1864 * * *$ \\
\hline & $(0.0068)$ & $(0.0500)$ \\
\hline \multirow[t]{2}{*}{ Debt to Equity } & $-0.0085^{*}$ & -0.0073 \\
\hline & $(0.0045)$ & $(0.0045)$ \\
\hline Property Type Dummy & Yes & Yes \\
\hline No. of obs & 915 & 974 \\
\hline Adj. R2 & 0.8426 & 0.8547 \\
\hline
\end{tabular}

This table reports the results of Fama-MacBeth cross-sectional regression. The dependent variable is the annual excess return netting of the T-bill rate. $r_{\text {firm,t-1 }}^{R E I T}$ is the lagged return. $\beta_{\text {firm,t-1 }}^{L R E M}$ stands for the lagged local beta for firm i. $\beta_{\text {firm,t }-1}^{\text {Stok }}$ is for the lagged stock market beta. $\beta_{i, t-1}^{S M B}, \beta_{i, t-1}^{H M L}$, and $\beta_{i, t-1}^{M O M}$ are the beta for Fama-French factors. Control variables include previous returns, change in market value, debt to equity ratio, market to book ratio, real estate investment growth and property type dummy. Standard errors are reported in parenthesis. $* * *, * *$ and $*$ denote significance at the $1 \%, 5 \%$ and $10 \%$ level, respectively

$$
V=\frac{M}{M^{2}} \bar{\beta}^{2} \sigma_{R E}^{2}+\frac{M(M-1)}{M^{2}} \bar{\beta}^{2} \sigma_{R E}^{2}=\bar{\beta}^{2} \sigma_{R E}^{2}
$$

So the variance will not be reduced when the REIT invests in more MSAs.

For REIT investors, it is still a non-diversifiable risk. If we assume $s_{i, t}$ as the predetermined weights used for the construction of portfolios including different REITs $i=1, \ldots, N$ and assuming that the following granularity conditions hold for all $\mathrm{t}$, we construct a portfolio: $\sum_{i=1}^{N} s_{i, t-1} R_{i, t}$. If we assume that real estate market return is independent with the stock return, and independent with the error term, we have:

$$
\begin{aligned}
\operatorname{var} & {\left[\sum_{i=1}^{N} s_{i, t-1} \sum_{m=1}^{M} w_{i, m}^{M S A} \beta_{m}^{M S A}\left(r_{\text {Nation }, t}^{N P I}-r_{f}\right)\right] } \\
& ==\sum_{i=1}^{N} s_{i, t-1}^{2} \operatorname{var}\left[\sum_{m=1}^{M} w_{i, m}^{M S A} \beta_{m}^{M S A}\left(r_{\text {Nation, }}^{N P I}-r_{f}\right)\right] \\
& +\sum_{i=1}^{N} s_{i, t-1} \sum_{j=1}^{N-1} s_{j, t-1} \operatorname{cov}\left[\sum_{m=1}^{M} w_{i, m}^{M S A} \beta_{m}^{M S A}\left(r_{\text {Nation, }}^{N P I}-r_{f}\right) \sum_{m=1}^{M} w_{j, m}^{M S A} \beta_{m}^{M S A}\left(r_{\text {Nation, },}^{N P I}-r_{f}\right)\right]
\end{aligned}
$$


Table 11 Diversification and Local real estate market risk - Robustness tests

\begin{tabular}{|c|c|c|c|c|}
\hline & $\begin{array}{l}\text { concentrated } \\
\mathrm{HHI}>0.14\end{array}$ & $\begin{array}{l}\text { diversified } \\
\mathrm{HHI}<=0.14\end{array}$ & $\begin{array}{l}\text { concentrated } \\
\mathrm{HHI}>0.25\end{array}$ & $\begin{array}{l}\text { diversified } \\
\mathrm{HHI}<=0.25\end{array}$ \\
\hline \multicolumn{5}{|c|}{ Panel A: Instrumented weights } \\
\hline \multirow{2}{*}{$\beta_{\text {firm }, t-1}^{L R E M}$} & $0.3391 * *$ & 0.0074 & $0.4499 * *$ & 0.0632 \\
\hline & $(0.1608)$ & $(0.0584)$ & $(0.1893)$ & $(0.1180)$ \\
\hline No. of obs & 545 & 687 & 385 & 847 \\
\hline Adj. R2 & 0.8881 & 0.9004 & 0.9499 & 0.8446 \\
\hline \multicolumn{5}{|c|}{ Panel B: Instrumented weights_SigFtest } \\
\hline \multirow[t]{2}{*}{$\beta_{\text {firm }, t-1}^{L R E M}$} & $0.3922 * *$ & -0.0229 & $0.3759^{*}$ & -0.0022 \\
\hline & $(0.1671)$ & $(0.1126)$ & $(0.2078)$ & $(0.1056)$ \\
\hline No. of obs & 391 & 291 & 290 & 392 \\
\hline Adj. R2 & 0.7519 & 0.9227 & 0.9168 & 0.8692 \\
\hline \multicolumn{5}{|c|}{ Panel C: Instrumented weights__Heckman } \\
\hline \multirow[t]{2}{*}{$\beta_{\text {firm }, t-1}^{L R E M}$} & $0.3229 * *$ & -0.2206 & $0.2858^{*}$ & -0.0082 \\
\hline & $(0.1410)$ & $(0.1474)$ & $(0.1652)$ & $(0.1173)$ \\
\hline No. of obs & 379 & 281 & 280 & 380 \\
\hline Adj. R2 & 0.8011 & 0.9328 & 0.9506 & 0.8792 \\
\hline \multicolumn{5}{|c|}{ Panel D: Time Varying MSA Beta } \\
\hline \multirow{2}{*}{$\beta_{\text {firm }, t-1}^{R E \text { local }}$} & $0.4414 * * *$ & 0.0070 & $0.5060 * * *$ & -0.0074 \\
\hline & $(0.1623)$ & $(0.0265)$ & $(0.1605)$ & $(0.0665)$ \\
\hline No. of obs & 503 & 620 & 358 & 765 \\
\hline Adj. R2 & 0.8977 & 0.9130 & 0.9665 & 0.8530 \\
\hline \multicolumn{5}{|c|}{ Panel E: Sector MSA Beta } \\
\hline \multirow[t]{2}{*}{$\beta_{\text {firm }, t-1}^{R E \text { local }}$} & $0.1092 *$ & -0.0241 & $0.3635^{* * *}$ & 0.0055 \\
\hline & $(0.0608)$ & $(0.0403)$ & $(0.0986)$ & $(0.0673)$ \\
\hline No. of obs & 498 & 615 & 356 & 757 \\
\hline Adj. R2 & 0.8918 & 0.9107 & 0.9617 & 0.8459 \\
\hline \multicolumn{5}{|c|}{ Panel F: leveraged and desmoothed MSA beta } \\
\hline \multirow[t]{2}{*}{$\beta_{\text {firm }, t-1}^{R E \text { local }}$} & $0.3668 * *$ & 0.0454 & $0.5234 * * *$ & 0.0771 \\
\hline & $(0.1555)$ & $(0.1375)$ & $(0.1704)$ & $(0.0787)$ \\
\hline No. of obs & 217 & 291 & 143 & 346 \\
\hline Adj. R2 & 0.9185 & 0.9868 & 0.9639 & 0.9701 \\
\hline \multicolumn{5}{|c|}{ Panel G: Excluding Negative Beta } \\
\hline \multirow[t]{2}{*}{$\beta_{\text {firm }, t-1}^{R E \text { local }}$} & $0.3055^{* *}$ & -0.0576 & $0.4927 * * *$ & 0.0988 \\
\hline & $(0.1380)$ & $(0.0517)$ & $(0.1654)$ & $(0.1033)$ \\
\hline No. of obs & 500 & 604 & 358 & 746 \\
\hline Adj. R2 & 0.8919 & 0.9151 & 0.9602 & 0.8559 \\
\hline \multicolumn{5}{|c|}{ Panel H: Using GDP shock } \\
\hline \multirow[t]{2}{*}{$\beta_{\text {firm }, t-1}^{R E \text { local }}$} & 0.1054 & 0.0920 & $0.1299 *$ & $0.1690 * *$ \\
\hline & $(0.0682)$ & $(0.1097)$ & $(0.0713)$ & $(0.0826)$ \\
\hline No. of obs & 492 & 559 & 356 & 695 \\
\hline Adj. R2 & 0.8894 & 0.9237 & 0.9546 & 0.8666 \\
\hline
\end{tabular}


Table 11 (continued)

$\begin{array}{llll}\text { concentrated } & \text { diversified } & \text { concentrated } & \text { diversified } \\ \mathrm{HHI}>0.14 & \mathrm{HHI}<=0.14 & \mathrm{HHI}>0.25 & \mathrm{HHI}<=0.25\end{array}$

Panel I: Excluding 2007-2015 in local beta calculation

$\begin{array}{lllll}\beta_{\text {firm }, t-1}^{\text {RE local }} & 0.0707 & -0.1355 & 0.1017^{*} & 0.0015 \\ & (0.0688) & (0.0869) & (0.0543) & (0.1121) \\ \text { No. of obs } & 476 & 490 & 349 & 617 \\ \text { Adj. R2 } & 0.8967 & 0.9303 & 0.9567 & 0.8851\end{array}$

Panel J: Excluding 2007-2015 in returns

$\begin{array}{lllll}\beta_{\text {firm }, t-1}^{\text {RE local }} & 0.0768 & -0.1184 & 0.1208^{*} & 0.0126 \\ & (0.0723) & (0.0835) & (0.0643) & (0.1203) \\ \text { No. of obs } & 475 & 476 & 349 & 602 \\ \text { Adj. R2 } & 0.8972 & 0.9328 & 0.9573 & 0.8882\end{array}$

This table reports the results of Fama-MacBeth cross-sectional regression. The dependent variable for Model 14 and 19 is the local beta. The dependent variable from Model 15 to 18 and from Model 20 to 23 is the annual excess return netting of the T-bill rate. $\beta_{f i r m, t-1}^{L R E M}$ stands for the lagged local beta for firm i. Control variables include previous returns, stock beta, change in market value, debt to equity ratio, market to book ratio, real estate investment growth and property type dummy. Standard errors are reported in parenthesis. $* * *, * *$ and $*$ denote significance at the $1 \%, 5 \%$ and $10 \%$ level, respectively

If we again assume the firm have equal weights in each MSA $\left(w_{i, m}^{M S A}=\frac{1}{M}\right)$, and the investor also has equal weights in each REIT $\left(s_{i, t-1}=\frac{1}{N}\right)$, and we denote $\bar{\beta}=\frac{1}{M} \sum_{m=1}^{M} \beta_{m}^{M S A}$ and $\bar{\beta}=\frac{1}{N} \sum_{i=1}^{N} \bar{\beta}$

$$
\begin{aligned}
\operatorname{var} & {\left[\sum_{i=1}^{N} s_{i, t-1} \sum_{m=1}^{M} w_{i, m}^{M S A} \beta_{m}^{M S A}\left(r_{\text {Nation }, t}^{N P I}-r_{f}\right)\right] } \\
& ==\sum_{i=1}^{N} s_{i, t-1}^{2} \bar{\beta}^{2} \sigma_{R E}^{2}+\sum_{i=1}^{N} s_{i, t-1} \sum_{j=1}^{N-1} s_{j, t-1} \bar{\beta}^{2} \sigma_{R E}^{2}=\frac{N}{N^{2}} \bar{\beta}^{2} \sigma_{R E}^{2}+\frac{N(N-1)}{N^{2}} \bar{\beta}^{2} \sigma_{R E}^{2}=\bar{\beta}^{2} \sigma_{R E}^{2}
\end{aligned}
$$

\section{So it is not diversifiable also for REIT investors.}

Acknowledgements Earlier versions of this work were presented at the 2019 ReCapNet conference in Mannheim and the 2019 International AREUEA Conference in Milano. We gratefully acknowledge the helpful comments of discussants and participants at those meetings and also the valuable comments of the referees and editorial team of the special issue.

Author Contribution Both authors contributed to the study conception and design and data collection. Data analysis was performed by Bing Zhu. The drafting and refining of the manuscript was shared by both authors. Both authors read and approved the final manuscript.

Funding This research was not funded by way of a research grant, nor supported by any organisation saving the authors' employing institutions.

\section{Declarations}

Conflict of Interest Neither author is aware of any conflict of interest in the preparation and publication of this research. Neither author is aware of any commercial interests that might have influenced the research or the interpretation of the results. The authors have no relevant financial or non-financial interests to disclose. 
Data Statement The data employed in this study are secondary: sources are specified in the main text. Most are from public domain but subscription-based data services, under academic licence to our respective institutions. As a result, the authors cannot., under the terms of the agreements, make the datasets used available, but results should be readily reproducible for anyone with the appropriate access.

Open Access This article is licensed under a Creative Commons Attribution 4.0 International License, which permits use, sharing, adaptation, distribution and reproduction in any medium or format, as long as you give appropriate credit to the original author(s) and the source, provide a link to the Creative Commons licence, and indicate if changes were made. The images or other third party material in this article are included in the article's Creative Commons licence, unless indicated otherwise in a credit line to the material. If material is not included in the article's Creative Commons licence and your intended use is not permitted by statutory regulation or exceeds the permitted use, you will need to obtain permission directly from the copyright holder. To view a copy of this licence, visit http://creativecommons.org/licen ses/by/4.0/.

\section{References}

Ambrose, B. W., Ehrlich, S. R., Hughes, W. T., \& Wachter, S. M. (2000). REIT economies of scale: Fact or fiction? Journal of Real Estate Finance and Economics, 20, 211-224.

Anderson, A., Clayton, J., Mackinnon, G., \& Sharma, R. (2005). REIT returns and pricing: The small cap value stock factor. Journal of Property Research, 22(4), 267-286.

Becker, B., Cronqvist, H., \& Fahlenbrach, R. (2011). Estimating the effects of large shareholders using a geographic instrument. Journal of Financial and Quantitative Analysis, 46, 907-942.

Bernile, G., Kumar, A., \& Sulaeman, J. (2015). Home away from home: Geography of information and local investors. Review of Financial Studies, 28, 2009-2049.

Brailsford, T. J. (1996). The empirical relationship between trading volume, returns and volatility. Accounting and Finance, 36, 89-111.

Capozza, D. R., \& Seguin, P. J. (1998). Managerial style and firm value. Real Estate Economics, 26, 131-150.

Capozza, D. R., \& Seguin, P. J. (1999). Focus, transparency and value: The REIT evidence. Real Estate Economics, 27, 587-619.

Chatrath, A., Liang, Y., \& Mcintosh, W. (2000). The asymmetric REIT-beta puzzle. Journal of Real Estate Portfolio Management, 6, 101-111.

Chiang, K., Lee, M.-L., \& Wisen, C. (2004). Another look at the asymmetric REIT-beta puzzle. Journal of Real Estate Research, 26, 25-42.

Conover, M. C., Friday, H. S., \& Howton, S. W. (2000). An analysis of the cross section of returns for EREITs using a varying-risk Beta model. Real Estate Economics, 28, 141-163.

Coval, J. D., \& Moskowitz, T. J. (2001). The geography of investment: Informed trading and asset prices. Journal of Political Economy, 109, 811-841.

Drennan, M. P., \& Kelly, H. F. (2011). Measuring urban agglomeration economies with office rents. Journal of Economic Geography, 11, 481-507.

Feng, Z., Pattanapanchai, M., Price, S. M., \& Sirmans, C. (2019). Geographic diversification in real estate investment trusts. Real Estate Economics.

Fisher, G., Steiner, E., Ventures, F. F., Titman, S., \& Viswanathan, A. (2020). How does property location influence investment risk and return? : Working Paper.

Fletcher, J. (2000). On the conditional relationship between beta and return in international stock returns. International Review of Financial Analysis, 9, 235-245.

Foster, F. D., \& Viswanathan, S. (1993). Variations in trading volume, return volatility, and trading costs: Evidence on recent price formation models. The Journal of Finance, 48, 187-211.

Fu, R., \& Gupta-Mukherjee, S. (2014). Geography, informal information flows and mutual fund portfolios. Financial Management, 43, 181-214.

Garcia, D., \& Norli, O. (2012). Geographic dispersion and stock returns. Journal of Financial Economics, 106, 547-565.

Garmaise, M. J., \& Moskowitz, T. J. (2004). Confronting information asymmetries: Evidence from real estate markets. Review of Financial Studies, 17, 405-437. 
Geltner, D., Macgregor, B. D., \& Schwann, G. M. (2003). Appraisal smoothing and price discovery in real estate markets. Urban Studies, 40, 1047-1064.

Glaeser, E. L., Gyourko, J., \& Saiz, A. (2008). Housing supply and housing bubbles. Journal of Urban Economics, 64, 198-217.

Glascock, J. L., Lu, C. L., \& So, R. W. (2000). Further evidence on the integration of REIT, bond, and stock returns. Journal of Real Estate Finance and Economics, 20, 177-194.

Gyourko, J., \& Nelling, E. (1996). Systematic risk and diversification in the equity REIT market. Real Estate Economics, 24, 493-515.

Gyourko, J., Hartley, J., \& Krimmel, J. (2019). The local residential land use regulatory environment across us housing markets: Evidence from a new Wharton index. National Bureau of Economic Research.

Hartzell, J. C., Sun, L. B., \& Titman, S. (2014). Institutional investors as monitors of corporate diversification decisions: Evidence from real estate investment trusts. Journal of Corporate Finance, 25, $61-72$.

Hoesli, M., \& Oikarinen, E. (2012). Are REITs real estate? Evidence from international sector level data. Journal of International Money and Finance, 31, 1823-1850.

Hong, H., Kubik, J. D., \& Stein, J. C. (2008). The only game in town: Stock-price consequences of local bias. Journal of Financial Economics, 90, 20-37.

Huang, P., \& Hueng, C. J. (2008). Conditional risk-return relationship in a time-varying beta model. Quantitative Finance, 8, 381-390.

Kroencke, T. A., Schindler, F., \& Steininger, B. I. (2018). The anatomy of public and private real estate return Premia. Journal of Real Estate Finance and Economics, 56, 500-523.

Li, L., \& Zhu, B. 2021. Trading and volatility in dual market: Theory and evidence from real estate. Real Estate Research.

Ling, D. C., Naranjo, A., \& Scheick, B. (2018a). Geographic portfolio allocations, property selection and performance attribution in public and private real estate markets. Real Estate Economics, 46, 404-448.

Ling, D. C., Naranjo, A., \& Scheick, B. 2018b. There's no place like home: Information asymmetries, Local Asset Concentration, and Portfolio Returns. Working Paper.

Ling, D. C., Wang, C., \& Zhou, T. 2020a. Asset productivity, local information diffusion, and commercial real estate returns. Local information Diffusion, and Commercial Real Estate Returns (June 17, 2020).

Ling, D. C., Wang, C., \& Zhou, T. (2020b). A first look at the impact of COVID-19 on commercial real estate prices: Asset-level evidence. The Review of Asset Pricing Studies, 10, 669-704.

Liu, C. H., Liu, P., \& Zhang, Z. (2019). Real assets, liquidation value and choice of financing. Real Estate Economics, 47, 478-508.

Lizieri, C. (2009). Towers of capital: Office markets and international financial services. Wiley-Blackwell.

Lizieri, C., \& Mekic, D. (2018). Real estate and global capital networks: Drilling into the City of London. In M. Hoyler, C. Parnreiter, \& A. Watson (Eds.), Global City makers. Edward Elgar.

Lizieri, C., Satchell, S., \& Wongwachara, W. (2012). Unsmoothing real estate returns: A regime-switching approach. Real Estate Economics, 40, 772-804.

Milcheva, S., Yildirim, Y., \& Zhu, B. (2021). Distance to headquarter and real estate equity performance. The Journal of Real Estate Finance and Economics, 63, 27-353.

Morawski, J., Rehkugler, H., \& Füss, R. (2008). Nature of listed real estate companies: Property or equity market? Financial Markets and Portfolio Management, 22, 101-126.

Oikarinen, E., Hoesli, M., \& Serrano, C. (2011). The long-run dynamics between direct and securitized real estate. Journal of Real Estate Research, 33, 73-103.

Pagliari, J. L., Scherer, K. A., \& Monopoli, R. T. (2005). Public versus private real estate equities: A more refined, long-term comparison. Real Estate Economics, 33, 147-187.

Peterson, J. D., \& Hsieh, C. H. (1997). Do common risk factors in the returns on stocks and bonds explain returns on REITs? Real Estate Economics, 25, 321-345.

Pirinsky, C., \& Wang, Q. H. (2006). Does corporate headquarters location matter for stock returns ? Journal of Finance, 61, 1991-2015.

Rehse, D., Riordan, R., Rottke, N. B., \& Zietz, J. (2019). The effects of uncertainty on market liquidity: Evidence from hurricane Sandy. Journal of Financial Economics, 134, 318-332

Schätz, A., \& Sebastian, S. P. (2011). Eine VECM-Analyse der Interaktion von Immobilienaktien mit Direktanlagen, Aktienmarkt und Realwirtschaft. Zeitschrift für Immobilienökonomie, 10, 83-107. 
Serrano, C., \& Hoesli, M. (2010). Are securitized real estate returns more predictable than stock returns? Journal of Real Estate Finance and Economics, 41, 170-192.

Shen, J., Hui, E., \& Fan, K. (2021). The beta anomaly in the REIT market. The Journal of Real Estate Finance and Economics, 63(3), 414-436.

Simon, S., \& Ng, W. L. (2009). The effect of real estate downturn on the link between REITs and the stock market. Journal of Real Estate Portfolio Management, 15, 211-219.

Sing, T. F., Tsai, I. C., \& Chen, M. C. (2006). Price dynamics in public and private housing markets in Singapore. Journal of Housing Economics, 15, 305-320.

Tang, G. Y., \& Shum, W. C. (2003). The conditional relationship between beta and returns: Recent evidence from international stock markets. International Business Review, 12, 109-126.

Tuzel, S., \& Zhang, M. B. (2017). Local risk, local factors, and asset prices. Journal of Finance, 72, 325-370.

Wang, C., Zhou, T., \& Glascock, J. L. (2017). Geographic proximity and managerial alignment: Evidence from asset sell-offs by real estate investment trusts. Working Paper.

Westerheide, P. (2006). Cointegration of real estate stocks and REITs with common stocks, bonds and consumer Price inflation: An international comparison. In N. B. Rottke (Ed.), Handbook real estate capital markets.

Xie, L. \& Milcheva, S. (2020), Proximity to COVID-19 Cases and Real Estate Stock Returns. Available at SSRN: https://ssrn.com/abstract=3641268

Zhu, B. \& Lizieri, C. (2021) Connected Markets through Global Real Estate Investments, Real Estate Economics, 49, 618-654.

Zhu, B., \& Milcheva, S. (2020). The pricing of spatial linkages in companies' underlying assets. The Journal of Real Estate Finance and Economics, 61, 443-475.

Publisher's Note Springer Nature remains neutral with regard to jurisdictional claims in published maps and institutional affiliations. 